\title{
How redistributive policies reduce market inequality: Education premiums in 22 OECD countries
}

\author{
David Weisstanner ${ }^{1}$ and Klaus Armingeon ${ }^{1}$ \\ ${ }^{1}$ Institute of Political Science, University of Bern \\ Correspondence: david.weisstanner@ipw.unibe.ch
}

Forthcoming in Socio-Economic Review: https://doi.org/10.1093/ser/mwy018

\begin{abstract}
What explains the large cross-country variation in the wage premium for higher education? Economic analyses of wage differentials by education point to technological change and globalisation, but we know little about the impact of different types of public policies. We argue that public education spending and tax-transfer policies contain the spread of "education premiums" through material incentives (decommodification) and attitudinal responses, i.e. changing attitudes towards education premiums and the motivation to request a maximum return on individual investment in education. The empirical analysis relies on a new dataset of education premiums constructed from Luxembourg Income Study microdata, covering 22 OECD countries between 1989 and 2014. We provide evidence that taxation levels and public education spending particularly affect education premium levels and changes within countries. For the literature on income inequality, these findings imply the need to pay attention more systematically to redistributive policies shaping the "market" distribution of incomes.
\end{abstract}

SER keywords: wages, inequality, education, public policy, redistribution

JEL classification: I24 Education and Inequality, I26 Returns to Education, I38 Government Policy • Provision and Effects of Welfare Programs

\section{Acknowledgements}

Previous versions of this paper were presented at the Swiss Political Science Association annual conference (St. Gallen, January 12, 2017), the INET Visitor Seminar (Oxford, February 7, 2017), the European Political Science Association annual conference (Milan, June 23, 2017) and the 24th International Conference of Europeanists (Glasgow, July 12, 2017). In addition to the participants at these presentations, we are grateful to Eric Guntermann, Silja Häusermann, Evelyne Huber, Thomas Kurer, Brian Nolan, John Stephens as well as two anonymous reviewers and Donald Tomaskovic-Devey for helpful comments and suggestions. 


\section{Introduction}

Wage differentials between high-educated and low-educated workers are called "education premiums”. They indicate differences in the returns to education. In this paper, we measure them as the percentage difference of median wages of full-time workers with tertiary education and the remaining full-time workers. While there is broad consensus that investment in education should pay off, it is far more controversial how large these premiums should be. Even from a liberal point of view, very large education premiums are problematic if they reproduce existing social inequalities and reduce mobility across generations.

A large comparative literature traces differences in income inequality and redistribution back to politics, institutions, and public policies (Bradley et al. 2003; Esping-Andersen 1990; Hall and Soskice 2001; Pontusson et al. 2002). However, this literature has little to say about wage differentials by educational attainment and wage premiums for higher education. In contrast, economists have explicitly focused on education premiums and argued that their increase in rich countries is the consequence of technological changes and globalisation (Acemoglu and Autor 2011; Freeman 1995; Goldin and Katz 2008; Katz and Murphy 1992). Technological progress and increasingly globalised labour and production markets have increased demand for high-skilled workers, while low-skilled workers have faced downward wage pressures. In this paper, we aim to connect these two research areas. Our research question asks whether different types of public policies explain the variation in education premiums.

We argue that the economic accounts involving technological change and globalisation inadequately explain the substantial cross-country variation in the level and development of wage premiums for workers with tertiary education. Conversely, we maintain that education premiums can be contained by a number of policies that are not only caused by economic structures and processes, but also by political choice. One important contribution of this paper is to provide an assessment of the impact of different public policies on wage inequality. The novelty in our approach is that we systematically examine the effects of education spending and 
other redistributive policies on "pre-fisc” (or “market”) income inequality. Studies of wage inequality often emphasize regulative labour market policies, and omit how tax-and-transfer policies might shape the market distribution of incomes.

Our analysis is based on a novel dataset on education premiums constructed from Luxembourg Income Study microdata, allowing us to compare 22 OECD countries between 1989 and 2014. Most prominently, we find that taxation and education policies contain the rise of education premiums. (a) A large tax state reduces the material incentives and the attitudinal motivation of highly qualified workers to exploit their strong position in the labour market. Firstly, a considerable part of additional income is taxed away. In this sense, one major mechanism underlying taxation is decommodification. Secondly, a policy-feedback mechanism (Kumlin and Stadelmann-Steffen 2014; Pierson 1993) may reduce the legitimacy of maximum returns to educational investments. (b) Large public spending on education is particularly advantageous for workers with non-tertiary education since their skill levels are lifted upwards. Large public education expenditures “address inequality from two directions: (i) enabling a larger fraction of adults to attain high productivity, rewarding jobs, and a reasonable standard of living; and (ii) raising the total supply of skills available to the economy, which in turn moderates the skill premium and reduces inequality” (Autor 2014: 850). With regard to public education spending in particular, we expect strong policy-feedback since it undercuts the moral foundations of requests for maximum returns on educational achievements due to private investment of effort and money.

This paper is organised as follows. In section 2, we first summarise explanations of wage differentials by education from the existing literature, before presenting our argument how education premiums are shaped by education policies, other redistributive policies and regulative policies. Section 3 presents our data and operationalisation. The results of our empirical analysis are discussed in section 4. 


\section{Returns to education, inequality and policy}

Income inequality in rich democracies is on the rise not only among the wealthiest members of society (Atkinson et al. 2011; Piketty and Saez 2014) but also among the “other 99 percent” (Autor 2014). A substantial economic literature has documented changes in the distribution of wages since the 1980s. The most prevalent model in this literature argues that technological change has been "skill biased” and has increased demand for high-skilled workers. As a consequence, the returns to skill or wage differentials between high-skilled and low-skilled workers are rising (Acemoglu and Autor 2011; Katz and Murphy 1992; Tinbergen 1975). Highskilled workers have also benefited from increasingly globalised labour and product markets, while relative demand for low-skilled workers tends to suffer from global competition (Freeman 1995). Globalisation allows for enhanced international division of labour, with high-tech production remaining in the developed market economies and production which relies on lowskilled labour going to less developed countries (Autor 2014).

According to this literature, skills are central to explaining wage inequality. Following the human capital framework, education is often used as a substitute measure for skills (Becker 1962; Mincer 1974; Murphy and Welch 1992), and educational attainment is a major determinant of skills (Hanushek et al. 2015). Holding the supply of education constant, skillbiased technological changes and globalisation reinforce wage inequalities between workers with varying educational attainment. Conversely, if the supply of high-educated workers increases, returns to education decrease (Card and Lemieux 2001; Katz and Murphy 1992; Katz et al. 1995) - inequality outcomes are determined by the notorious race between education and technology (Goldin and Katz 2008). In sum, education premiums are a crucial source of wage inequality, determined mainly by factors of supply and demand in the labour market.

However, the empirical evidence is ambiguous, documenting strong variation in education premiums across countries (Autor 2014; Hanushek et al. 2015). The same investment in education yields very different returns in international comparison. From an economic point of 
view and assuming perfectly competitive labour markets, we would expect similar rates of return everywhere. This implies that the economic efficiency of labour markets is reduced by different policies writ large. Indeed, some comparative studies have found that labour market regulations or union strength are associated with lower education premiums (Crivellaro 2014; Hanushek et al. 2015; Katz et al. 1995), while others find no effect of labour market institutions (van der Velden and Bijlsma 2016). Acemoglu (2002) develops a theoretical argument that labour market institutions are crucial because they affect the direction of technological change: European firms, operating in densely regulated labour markets, have more incentives to raise low-skilled workers' productivity, therefore technological change is less skill-biased compared to the US.

Overall, existing analyses of education premiums have looked at a relatively limited set of policies and there is scarce theoretical and empirical guidance about which policies matter for wage differentials by education. Our approach therefore builds on the comparative political economy literature on welfare states and income inequality in order to more systematically identify the types of policies expected to affect education premium developments across countries. At the same time, we go beyond this literature by focusing exclusively on the proximate causal link between policies and education premiums (Figure 1). While there has been extensive research on the political and institutional determinants of policy configurations (link 1. to 2.) and of inequality outcomes (link 1. to 3.), the actual policy channels through which politics and institutions affect wage or income inequality (link 2. to 3.) remain less explored.

\section{[Figure 1]}

Several studies in comparative political economy have explored the effects of selected policies on overall wage inequality, focusing mainly on wage-setting institutions and labour market regulations (e.g. Pontusson et al. 2002; Wallerstein 1999). But these approaches remain incomplete in three regards. 
First, most studies discount the possibility that "market" income distributions may differ along features of the welfare state (Bergh 2005), arguably due to the redistributive effects of tax revenues and benefit expenditures. These effects alter incentives for specific behaviour on market. For example, if citizens know that they may consume additional income (rather than being taxed), they may exploit their market position and be more committed to bargain for higher wages than those who know that most of that income will be turned into taxes and social security contributions.

Second, few studies focus on the particular role of education policies. Being part of the distributive policies of the modern welfare state (Iversen and Stephens 2008), their redistributive implications are complex (Ansell 2010; Busemeyer 2015, 2017) and are probably more farreaching for education premiums than other redistributive policies such as public spending in other policy fields.

Third, these studies neglect policy feedback (Kumlin and Stadelmann-Steffen 2014; Pierson 1993). By policy feedback, we mean policy effects on attitudes beyond a sheer economic calculus in particular. Policies may not only change the payoff matrix of a rational citizen maximizing her objective utility. Rather, policies may influence norms and behaviour by undermining the rationale and legitimacy of pursuing maximum returns on individual investment in educational credentials. For example, if the state creates equality of opportunity in access to high-quality education, it is harder to argue for high returns on education due to the private financing of higher education.

As a consequence, in explaining international variation of education premiums, we consider both regulative policies (such as labour market regulation) and (re-)distributive policies (welfare state and education policies). While we remain agnostic about the relative importance of a specific policy for education premiums, we expect that strong public commitment in any of these policy areas constrains market principles such as competition, individual responsibility, 
and decentralised decision-making (Höpner et al. 2014), yields reduced returns to education and alters the attitudinal basis of requests for a large spread of education premiums.

Education policies concern education finance in the first place. With high public investment in the education sector, access to educational attainments is hardly restricted to those who (or whose family) can afford it (Busemeyer 2015). This increases the pool of workers who have the cognitive prerequisites for high-skilled occupations. Likewise, a large system of public education increases the supply of highly qualified labour and gives workers without tertiary education the chance of reaching a relatively high level of educational attainments and related skills. If the gap between supply of very qualified labour and the technologically driven demand of highly skilled workers is reduced, wages for these workers will decline relatively (Goldin and Katz 2008). Aside from that, the combination of public investment in education and generous social protection works as insurance to invest in firm-specific or industry-specific skills rather than in general transferable skills, which prevents the gap often prevalent in general skills systems with low wages for early school leavers (Busemeyer 2015; Estevez-Abe et al. 2001; Iversen and Soskice 2001). Large public expenditure on education makes private spending for education less essential. A large private sector tends to limit access to higher education to pupils whose families can afford enrolment in more prestigious private schools. Along this logic, privatised education systems result in higher educational inequalities compared to public education systems (Busemeyer and Iversen 2014).

The shares of private and public financing of education may also alter the rationale for maximizing individual utility. Individuals who had to fund education by their own means are more likely to claim high wage premiums as compensation for their private investment (Busemeyer 2013) and possibly to repay accumulated student debt. Finally, there may be a policy feedback (Kumlin and Stadelmann-Steffen 2014; Pierson 1993) on attitudes and norms with regard to the size of public and private education spending. The more the state creates equality of opportunity in education, the less convincing and legitimate is the argument that 
(private) financial investment in education should produce a maximum of returns - since these investments are marginal and the major difference in educational credentials is due to talent and intellectual effort. This leads to a first hypothesis about education policies:

H1: Strong public education finance policies reduce education premiums.

Other redistributive welfare policies concern the role of state intervention in the economy.

Welfare states have both redistributive and insurance functions (Moene and Wallerstein 2001). We expect welfare policies to influence the distribution of gross labour earnings by education through various channels. First, building on Esping-Andersen’s (1990) idea of decommodification, generous welfare policies provide options to maintain a living outside the labour market and therefore increase the bargaining power of low-educated workers. For example, a generous unemployment insurance or a generous system of social assistance raise the reservation wage of workers, thereby compressing the wage structure (Wallerstein 1999). Second, the larger the public sector, the larger the segment of the workforce whose wages are settled in the public-political realm as compared to those whose wages are a function of private market processes. Typically, wages are more compressed in the public sector than in the private sector (Katz and Krueger 1991). Third, a large tax state is another form of decommodification. High marginal tax rates reduce market inequality in the field of net wages (Kakwani 1977). In addition, a large share of taxes and social contributions in labour costs reduce the incentive to fight for strong wage increases at the top level of the income distribution since a large part of this increase will be taxed away. Fourth, if non-wage labour costs are relatively high, this discourages employers from creating new jobs. This applies particularly to low-productivity jobs in the private sector that are typically also low-skill jobs. Employers have strong incentives to substitute these jobs by investments, thereby reducing the share of workers with low skills (Scharpf 2000, 2001). Finally, there may again be a feedback effect on attitudes. If the economy is highly politicized by redistributive policies, requests for high returns on education are difficult 
to legitimize with regard to economic competitiveness and efficient markets. This leads to a second hypothesis:

H2: Strong redistributive welfare policies such as a large tax state reduce education premiums.

Regulative labour market policies create legal or informal norms that actors must follow. Such policies may effectively limit market forces as they institutionalize floor and ceiling effects in the wage-setting system. First, policies such as a broad coverage of collective agreements or the coordination and centralisation of wage bargaining impose a floor on lower wages and increase the bargaining strength of workers relative to employers (Pontusson et al. 2002; Rueda and Pontusson 2000; Wallerstein 1999). At the upper end of the income distribution, the presence of centralised or coordinated bargaining and strong unions may implicitly lead to lower wages for higher-paid workers, including management pay (Huber et al. 2016). Broad coverage of collective agreements, bargaining centralization and coordination are correlated with strong trade unions in terms of union unity, density, or centralization.

The second component of regulative policies concerns employment protection. Employment protection legislation improves the bargaining position of (low-skilled) workers who are in danger of being laid off if they do not accept lower wages. In combination with higher reservation wages for the unemployed, employment protection compresses wage differentials given that unemployment disproportionally affects low-educated workers (OECD 2011; Oesch 2010). This leads to our final hypothesis:

H3: Strong regulative labour market policies reduce education premiums.

In the empirical analyses that follow, we will present a set of policies that can be assigned to the two dimensions of education/welfare state policies and regulative policies. We will show that taxation and public education policies in particular are significantly associated with the development of education premiums. The analysis will also introduce measures for the standard 
explanations of skill demand (i.e., technological change and globalisation) and supply (i.e., the share of workers with tertiary education) of education premiums.

\section{Data, operationalisation and methods}

The empirical analysis compares education premiums in 22 OECD countries ${ }^{1}$ from the early 1990s to 2014. We operationalise education premiums as the percentage difference of median pre-tax earnings of full-time workers with tertiary education relative to workers without tertiary education. This measure excludes unemployed and retired workers. ${ }^{2}$ This is the commonly used measure of “college wage premiums” (e.g. Card and Lemieux 2001). Although countries differ in the importance of tertiary education relative to non-academic tracks and their systems of vocational education and training (Busemeyer 2015; Estevez-Abe et al. 2001), wage differentials between workers with tertiary and non-tertiary educational attainment are easily distinguishable and thus provide a meaningful reference for changes over time. ${ }^{3}$

We use harmonized income surveys from the Luxembourg Income Study database (LIS 2017) and rely on three assumptions to increase the coverage of countries and years. First, where incomes were recorded net of tax only, we extrapolate gross earnings premiums from percentage changes in net person-level earnings (or net equivalized household earnings, where no personlevel income data is available). Second, for Denmark, France, Norway and Sweden, we lack information to distinguish full-time workers in some survey years. We therefore extend the

\footnotetext{
${ }^{1}$ Australia, Austria, Belgium, Canada, Czech Republic, Denmark, Finland, France, Germany, Greece, Ireland, Italy, Luxembourg, Netherlands, Norway, Poland, Slovak Republic, Spain, Sweden, Switzerland, United Kingdom, United States.

${ }^{2}$ We restrict the working-age population to full-time dependent employees aged between 25 and 59 . Gross labor earnings below $1 \%$ of mean earnings (including zero) were coded as missing. The remaining earnings were bottomcoded at the first percentile and top-coded at the 99th percentile.

${ }^{3}$ Of course, in the later multivariate analyses we need to control for changes in the share of workers with tertiary education to remove compositional changes through the expansion of higher education. An alternative premium measure would be to split the population into two educational groups of about equal size (half low-educated, half high-educated), with varying cutoff points. We opt against this option because LIS education categories were recorded very heterogeneously. When detailed information on education categories is missing, this results in volatile and uneven group sizes. However, the correlation between the two measures of education premiums is high at 0.81 $(\mathrm{N}=123)$.
} 
sample to all dependent employees in these countries. If anything, including part-time workers overestimates education premiums because part-time workers are more likely to be less educated. Third, for the UK, we lack categorical education data before 1999. Thus, we count workers who completed education after the age of 21 as tertiary. Our results are substantially the same if we drop the countries affected by these assumptions.

Table 1 displays education premiums at the time around 1995, 2007, and 2013 (for the full dataset, see Table A1 in the online appendix). The 22 countries are grouped along geographic and welfare state clusters. The most striking feature of Table 1 is the large variation of education premiums across countries, in terms of both levels and changes over time. Education premiums are comparatively large in the Anglo-Saxon countries. In the United States in 2013, the education premium is estimated at 0.67 . In other words, the median worker with tertiary education’s earnings exceeded those without tertiary education by about $67 \%(\$ 55,000 / \$ 33,000$ 1). Over time, premiums in the Anglo-Saxon countries increased only moderately between 1995 and 2007 and even decreased in Australia and the UK. ${ }^{4}$ At the other end of the spectrum, education premiums remained lowest in the Nordic countries across the whole period. In Southern and Eastern European countries, education premiums started from high levels in the mid-1990s but decreased throughout the 2000s (with the exception of Greece). Finally, education premiums increased significantly in continental European countries such as Austria, Germany, the Netherlands and Switzerland. In contrast, they wage differentials are declining in France.

\section{[Table 1]}

Throughout the Great Recession, we depict a pattern of larger volatility in several countries but no general reversion of the preceding trends. Among the countries most severely affected by

\footnotetext{
${ }^{4}$ Note again that LIS microdata lack categorical data on educational attainment for the UK, which could underestimate wage inequalities by education. In any case, all results are robust without the UK.
} 
high unemployment, premiums increased strongly in Spain, literally collapsed in Greece and declined in Ireland. The effect of economic downturns on education wage differentials is ambiguous a priori because it depends on the extent that unemployment is concentrated among the low-educated (Pontusson and Weisstanner 2018).

\section{Independent variables}

Following our theoretical framework above, we ask whether policies explain this large variation of education premiums, and specifically, which policies seem most effective to reduce wage differentials by education. We focus on seven indicators for education policies, other redistributive policies, and regulative policies. ${ }^{5}$ As discussed in the previous section, our measures for education policies mainly concern education finance, which we measure with the two indicators of public expenditures on education and private expenditures on education as a percentage of GDP (OECD 2016). Our first indicator for redistributive policies is taxation, measured as tax rates for single persons with average wage (income tax plus social contributions, or so-called “tax wedges”) (OECD 2012, 2017). The next indicator refers to non-elderly social expenditure (public and mandatory social expenditure excluding old age and health care).

Finally, as measures for regulative policies we include the bargaining coverage rate and the OECD indicators of employment protection legislation (EPL) for regular contracts and EPL for temporary/fixed-term contracts.

Our analysis controls for a number of standard economic explanations of education premiums. First, we control for shifts in skill supply with the share of tertiary education among full-time workers (estimated on the basis of the same LIS microdata which were used to measure the dependent variable). Trade openness is measured by the sum of exports and imports as a share of GDP. Next, we add change in total factor productivity as a widely used measure for

\footnotetext{
${ }^{5}$ Unless indicated otherwise, all variables are from Armingeon et al. (2016).
} 
technological change (European Commission 2016). Finally, we control for changes in unemployment, which are relevant because we have many observations in the recession period 2007-2013. Our dataset is unbalanced because LIS data come in survey waves and are available only in intervals every few years which are different from country to country. For all independent variables, we therefore calculate averages between two LIS microdata observations based on annual data (i.e. across the period since the previous LIS observation) (see Lupu and Pontusson 2011: 324).

\section{Model specification}

The statistical analysis proceeds in two specifications. First, we estimate pooled OLS regression models of education premium levels which, we assume, primarily capture the cross-sectional effects of policies. The main problem with this specification is that high multicollinearity among the policy indicators prevents the inclusion of several policy variables at once. ${ }^{6}$ Therefore, we estimate separate models including only one policy indicator in each model. Wooldridge tests indicate that there is strong first-order autocorrelation in the education premiums series. We deal with this by estimating AR(1) error processes for each country by Prais-Winsten transformation. We also estimate an additional set of models which include a lagged dependent variable and tends to eliminate autocorrelation (Beck and Katz 1995).

The second specification is based on fixed-effects (FE) regressions, explicitly addressing the question of dynamics within countries. FE regressions in essence demean all variables, after which the multicollinearity issues of the first specification turn out to be resolved. As a consequence, we are able to include all seven policy indicators simultaneously and assess

\footnotetext{
${ }^{6}$ A model simultaneously including all seven policy indicators (without country fixed effects) results in critical VIF values between 7 and 68 for the policy indicators. An alternative strategy to deal with multicollinearity would be to generate factor variables of the policy indicators. Principal-component factor analysis with orthogonal varimax rotation yields one factor mainly explained by public education spending and non-elderly social expenditure and a second factor mainly explained by the other five policy indicators. Both factors have strongly significant negative effects on education premium levels, similar to the analyses presented below (results available from authors).
} 
whether deviations from the policy average within countries have an effect on the dynamics of education premiums. The downside of this procedure is the elimination of unit heterogeneity and of any time-invariant characteristics. Rather than estimating FE models with education premium levels and a lagged dependent variable, which subtracts the mean value of $y$ and each $X$ from the respective variable and therewith creates a correlation between regressor and error ("Nickell bias” (Nickell 1981)), we estimate FE regressions of education premium changes (first differences). However, we also estimate one model with premium levels and lagged dependent variable as robustness check. Our FE specifications raise no significant autocorrelation issues.

In the analyses to be discussed in the next section, we drop Luxembourg due to missing data on policy variables and Belgium because we have only one observation of premium changes, which makes it irrelevant in the FE specifications. Our multivariate sample then consists of 92 observations in 20 countries from 1997 to 2014, (4.6 observations per country on average $)^{7}$. All models are estimated with panel-corrected standard errors, accounting for panel heteroskedasticity and the unbalanced structure of the dataset (Beck and Katz 1995). Finally, all models include LIS wave dummies (for surveys around 2000/04/07/10/13) to account for common shocks (results are substantially identical without period dummies).

A causal analysis of attitudinal responses and policy feedbacks is beyond the scope of this paper. We just attempt to make the claim of such feedback plausible by simple bivariate correlations. We use the International Social Survey Programme (ISSP) module in 2009 on social inequality. We measure the extent to which investment in education should yield income returns by the question: "In deciding how much people ought to earn, how important should ... be, in your opinion ... the number of years spent in education and training?’ The respondents could answer on a scale from essential (1), very important (2), fairly important (3), not very important (4) and not important at all (5). We calculated the arithmetic mean for each country.

\footnotetext{
${ }^{7}$ In addition, education premium changes in 1997 derive from the levels of the preceding period in the early 1990 s.
} 
For presentational reasons, we reversed the scale, with (1) being not important at all and (5)

essential. For 21 countries, this gives our study an indicator for the attitudes towards returns on education. The higher the value the more supportive citizens are for the norm that individual effort and ambition in education should yield high returns in terms of wages.

\section{Findings}

The first part of the statistical analysis addresses the associations of single policies to education premium levels. Table 2 shows the coefficients of the policy indicators from pooled OLS regressions of education premium levels on policies and a set of economic control variables. While this first set of models allows only limited conclusions on the relationship between policies and education premium changes, they should be read as descriptive evidence on the cross-sectional association between policies and premiums. As shown in the online appendix containing the full results (Tables A2 and A3), control variables are generally in the expected direction: Technological change (measured by factor productivity change) is significantly related to higher education premiums. Increasing the skill supply (share of workers with tertiary education) is associated with lower premiums, while the opposite is the case for changes in unemployment. Trade openness is not significantly related to education premiums. As mentioned in the previous section, strong multicollinearity among the policy indicators prevents us from including several policies at once. Therefore, the coefficients in Table 2 are based on separate models including one policy indicator at a time. ${ }^{8}$

[Table 2]

\footnotetext{
${ }^{8}$ We compared the results in Table 2 to models that include two policies at the same time (available upon request). These models generally confirm the significant associations of our policy variables with education premium levels. However, standard errors might be seriously inflated in some constellations. For example, the association of public education spending is robust across all constellations except when controlling for non-elderly social spending which is not surprising given the strong correlation between the two policies $(r=0.80, N=92)$.
} 
Turning first to the models estimated without a lagged dependent variable (LDV), we find that six of seven policy variables are significantly related to education premium levels in the expected direction. Non-elderly social spending and public education spending have the strongest explanatory power, with $\mathrm{R}^{2}$ increasing from 0.09 in the model without policies to 0.44 and $0.35 .{ }^{9}$ In substantive terms, increasing non-elderly public social spending by three percentage points (about 1 standard deviation) is associated with lower education premiums by almost eight percentage points. Increasing public education spending by one percentage point (about 1 standard deviation) is associated with lower education premiums by almost six percentage points.

Additionally, Table 2 reveals significant negative associations between education premiums and average tax rates, employment protection (EPL) for regular workers, and bargaining coverage. Private education spending is significantly related to higher education premiums. Temporary employment regulation is not significantly correlated with education premiums. Turning to the last column of Table 2, these findings are broadly corroborated when estimating the same models with a lagged dependent variable. Unsurprisingly, the LDV coefficients are close to 1 and dramatically improve the explained variance of the models. However, all policy indicators are significantly related to education premiums in the theoretically expected direction at least at the $90 \%$ level. The substantive effects increase for most policies: for example, a standard deviation change in taxes lowers the long-run equilibrium of education premiums by more than eight percentage points. ${ }^{10}$

Overall, the results in Table 2 provide substantial support that policies contribute to explaining the international variation in education premiums. However, exactly because of the

\footnotetext{
${ }^{9} \mathrm{R}^{2}$ calculated without the AR(1) error processes. Given the strong autocorrelation in the series, including AR(1) error processes reflects the strong persistency in the data and increases $\mathrm{R}^{2}$ to a range between 0.86 and 0.94 (see Table A2).

${ }^{10}$ The LDV models induce dynamics: education premiums in this specification adjust slowly to a change in policy (partial adjustment model). Long-run effects can be calculated by dividing policy coefficients by one minus the LDV coefficient (De Boef and Keele 2008).
} 
large cross-country variation, these models of education premium levels are much better suited to explain the cross-sectional associations between policies and premiums than to explain the dynamics of premiums over time. There is no certainty that policies have the same effects on cross-country level differences and on changes over time. For example, among countries with historically broad coverage of bargaining agreements, premiums have steadily increased in Austria, Germany, and the Netherlands, while they have decreased in France, Denmark, and Sweden. Among countries with historically low coverage rates, premiums have increased in the US, Canada, and Switzerland, while they have declined in Poland, Slovakia, and the UK. To address this divergence in trajectories, the second part of our analysis focuses on changes in education premiums within countries.

Table 3 shows the results of pooled OLS regressions with country fixed effects (FE). Models 1 to 3 in Table 3 have education premium changes (first differences) as dependent variable, while Model 4 uses premium levels and a lagged dependent variable. FE models are equivalent to a transformation where all variables are demeaned within countries. This transformation resolves the problem of multicollinearity among our policy variables (of course, at the price of removing level heterogeneity between countries). The economic control variables are again consistent with theoretical expectations: Trade openness, technological change, and unemployment contribute to higher education premiums within countries, while the skill supply decreases education premiums.

\section{[Table 3]}

The second model in Table 3 adds all seven policy indicators to the basic economic model. The results are clear: Both public education spending and average tax rates significantly reduce education premiums within countries. The remaining five policies are all statistically insignificant predictors of education premium changes within countries. The strong associations 
of public education spending and taxes with lower changes of education premiums are confirmed in the third model which excludes the insignificant policy variables. The same conclusion holds for the fourth model with education premium levels as dependent variable and controlling for lagged premium levels. Again, taxes and public education spending are significant at the 99 percent level. The substantive magnitude of the effects for these two policies is large: A standard deviation change in policies leads to reduced education premium changes by 12 percentage points (taxes) and 6 percentage points (public education spending) (Model 3). The results are not driven by the influence of single countries: The two policy coefficients in Model 3 remain significant at the 95 percent level (at least) when excluding one country at a time.

In further analyses reported in the online appendix, we estimated error correction models (ECM) that allow differentiating between the impact of levels as well as changes in our policy indicators on education premium dynamics. ${ }^{11}$ The results of the ECM models show that the bulk of policy effects on education premiums occur over the long-term, with only a minor role of short-term policy changes. The ECM models without fixed effects corroborate the findings from Table 2 and provide strong support for a long-term dynamic relationship between each of our policy indicators and education premiums. Focusing on a within-country perspective, the fixedeffects ECM models underline the strong impact of redistributive policies (public education spending, taxation and social spending) on changes in the long-term equilibrium of education premiums.

The distinction between short-term and long-term impact of policies in the ECM models also hints at the reasons for the divergence in policy effects between the models without fixed effects (picking up cross-national differences) and the fixed-effects models (picking up changes within countries over time). First, the relationship between policies and education premiums is characterized by long-term associations that are not easily captured by fixed-effects models.

\footnotetext{
${ }^{11}$ See Tables A4, A5, A6 and A7 in the online appendix. While ECM models potentially suffer from our low sample size, we find that the results allow for generally robust conclusions.
} 
Second, with regard to regulative policies - for which we find no consistent within-country associations with education premiums - it is important to note that we observe only limited changes over time. This is apparent, for instance, in the OECD-based indicators for employment protection for regular and temporary workers. With the limited number of countries that experienced changes over time, the fixed-effects specifications are not well suited to assess the impact of changes in regulative policies. A more promising view, beyond the scope of this paper, would be to conceptualize policy configurations and identify those policy areas where significant changes to the policy configuration have occurred.

Finally, one might expect that the strong effects of public education spending on education premiums are distinct for spending on different levels of education. In contrast to public spending at lower educational levels, public spending on tertiary education increases income inequality if access to universities is biased towards the wealthy (Ansell 2008). However, we still expect that public expenditures on higher education decrease education premiums because of the process of “depreciation” of tertiary education when the supply of graduates increases.

Consistent with our argument, we find strongly significant negative effects of public education spending even when we restrict expenditures to spending on tertiary education. ${ }^{12}$

Turning to the question of policy feedback on attitudes and norms, we correlated the indicator of support for high returns on educational effort and ambition with education premiums (Figure 2) and indicators of education spending and redistributive policies (Figure 3). Figure 2 shows strong support for the notion that education premiums are strongly correlated with support for high wage returns $(r=0.68, \mathrm{p}<0.01, \mathrm{~N}=17)$.

[Figure 2]

\footnotetext{
${ }^{12}$ Replicating Table 2, the coefficient for public spending on tertiary education is $-19.01(\mathrm{p}<0.001)$ in the model without LDV and $-2.13(\mathrm{p}<0.1)$ in the model with LDV. In Table 3 (Model 3), the coefficient for public spending on tertiary education is $-14.58(\mathrm{p}<0.001)$. We also find substantially similar effects when restricting public education spending to non-tertiary expenditure.
} 
Likewise, Figure 3 reveals a strong association between public education spending and lower support for high returns, especially when the deviant case of Japan is excluded $(r=-0.68, p<0.01$, $\mathrm{N}=20$; including Japan, the correlation drops to $\mathrm{r}=-0.37, \mathrm{p}=0.10, \mathrm{~N}=20$ ). If we measure the "politicization” of the economy by non-elderly social spending, there is again a strong correlation after the exclusion of Japan $(r=-0.65, p<0.01, N=20)$.

[Figure 3]

These descriptive statistics are in support of a strong attitudinal policy feedback. The associations between redistributive policies and education premiums do not solely rely on the causal mechanism of material incentives and rational citizens maximizing their objective utility. Rather, there are good reasons to assume that educational and redistributive policies have a parallel impact on attitudes and norms. Strong redistributive policies affect citizens in such a way that they become more reluctant to claim high returns on their educational investment in terms of money and time.

\section{Conclusion}

In 2013, the education premium in the US has been 67\%, in Norway it was $20 \%$. These are huge differences and they can have a large impact for the quality of life in these countries. Imagine a society such as the US in which the median college graduate earns about 1.7 times of the income of a median worker with non-tertiary education. This not only has implications for income inequality. It may also intensify processes of social closure. Highly educated parents will be very much concerned that their offspring attends college even if his or her intellectual talents are rather limited, while parents with low education may lack the resources to send their bright children to university. In contrast, an education premium of $20 \%$ may be sufficient monetary 
incentive for students to invest time and energy for excelling in school and attending college. But in this society with modest education premiums, up- and downward social mobility will be greater (or at least less dramatic) because educational background does not pre-distribute the opportunities for decent earnings to the same degree. There will be much less stress in these societies due to individual challenges of up- and downward social mobility, although good students may be as good, or even better, than in societies with large education premiums.

As a main contribution of this paper, we assembled a novel dataset on education premiums for 22 OECD countries from the 1990s to 2014, based on the Luxembourg Income Study. To the best of our knowledge, this dataset is of a better quality (in terms of comparability) and a broader coverage (in time and across countries) than any other dataset on education wage premiums available for scientific research.

Our empirical analysis shows that the standard models in economics for the explanation of education premiums are mis-specified. We could corroborate earlier findings about the economic determinants of education premiums, namely that economic globalization and technological change put upward pressure on wage inequality. However, we also provide systematic evidence that public policies are highly relevant for international and intertemporal variation of education premiums. The most important finding is that both level and change of education premiums depend critically on public spending for education and the size of the tax state. The underlying causal processes are the lifting of skill levels of the lower part of the educational hierarchy and decommodification, as well as the impact of state activities in the field of welfare spending, and education spending in particular, on supporting attitudes for maximum returns on education.

In this paper, we could not study the causes of these policy differences. They are analysed in many studies and we know that they are not the sole result of social and economic structures, but also of politics and institutions. Hence, it is not only economic fate but also political choice whether education premiums are modest and stagnant, or whether they are large and increasing. 


\section{References}

Acemoglu, Daron (2002), 'Technical Change, Inequality, and the Labor Market', Journal of Economic Literature, 40 (1), 7-72.

Acemoglu, Daron and Autor, David (2011), 'Skills, Tasks and Technologies: Implications for Employment and Earnings', in Orley Ashenfelter and David Card (eds.), Handbook of Labor Economics (4B; Amsterdam: Elsevier), 1043-171.

Ansell, Ben W. (2008), 'University Challenges: Explaining Institutional Change in Higher Education', World Politics, 60 (2), 189-230.

--- (2010), From the Ballot to the Blackboard: The Redistributive Political Economy of Education (New York: Cambridge University Press).

Atkinson, Anthony B., Piketty, Thomas, and Saez, Emmanuel (2011), 'Top Incomes in the Long Run of History', Journal of Economic Literature, 49 (1), 3-71.

Autor, David H. (2014), 'Skills, education, and the rise of earnings inequality among the "other 99 percent”', Science, 344 (6186), 843-51.

Beck, Nathaniel and Katz, Jonathan N. (1995), 'What to do (and not to do) with Time-Series Cross-Section Data', The American Political Science Review, 89 (3), 634-47.

Becker, Gary S. (1962), 'Investment in Human Capital: A Theoretical Analysis', Journal of Political Economy, 70 (5), 9-49.

Bergh, Andreas (2005), 'On the Counterfactual Problem of Welfare State Research: How Can We Measure Redistribution?', European Sociological Review, 21 (4), 345-57.

Bradley, David, Huber, Evelyne, Moller, Stephanie, Nielsen, François, and Stephens, John D. (2003), 'Distribution and Redistribution in Postindustrial Democracies', World Politics, 55 (2), 193-228.

Busemeyer, Marius R. (2013), 'Education Funding and Individual Preferences for Redistribution', European Sociological Review, 29 (6), 1122-33.

--- (2015), Skills and Inequality. Partisan Politics and the Political Economy of Education Reforms in Western Welfare States (Cambridge: Cambridge University Press).

--- (2017), 'Education and the Welfare State: A Short Comment on a Complex Relationship', PS: Political Science \& Politics, 50 (2), 426-27.

Busemeyer, Marius R. and Iversen, Torben (2014), 'The politics of opting out: explaining educational financing and popular support for public spending', Socio-Economic Review, 12 (2), 299-328.

Card, David and Lemieux, Thomas (2001), 'Can Falling Supply Explain the Rising Return to College for Younger Men? A Cohort-Based Analysis', The Quarterly Journal of Economics, 116 (2), 705-46.

Crivellaro, Elena (2014), 'College wage premium over time: trends in Europe in the last 15 years', University of Venice, Department of Economics Working Paper 03.

Esping-Andersen, Gøsta (1990), The Three Worlds of Welfare Capitalism (Princeton: Princeton University Press).

Estevez-Abe, Margarita, Iversen, Torben, and Soskice, David (2001), 'Social Protection and the Formation of Skills: A Reinterpretation of the Welfare State', in Peter A. Hall and David Soskice (eds.), Varieties of Capitalism. The Institutional Foundations of Comparative Advantage (Oxford: Oxford University Press), 145-83.

European Commission (2016), AMECO database (Variable ZVGDF) (http://ec.europa.eu/economy_finance/ameco/user (accessed 2016-11-29)).

Freeman, Richard B. (1995), 'Are Your Wages Set in Beijing?', Journal of Economic Perspectives, 9 (3), 15-32.

Goldin, Claudia and Katz, Lawrence F. (2008), The Race between Education and Technology (Cambridge, MA: Harvard University Press).

Hall, Peter A. and Soskice, David (eds.) (2001), Varieties of Capitalism: The Institutional Foundations of Comparative Advantage (Oxford: Oxford University Press). 
Hanushek, Eric A., Schwerdt, Guido, Wiederhold, Simon, and Woessmann, Ludger (2015), 'Returns to skills around the world: Evidence from PIAAC', European Economic Review, 73, 103-30.

Höpner, Martin, Petring, Alexander, Seikel, Daniel, and Werner, Benjamin (2014), 'Liberalization Policy. An Empirical Analysis of Economic and Social Interventions in Western Democracies', WSI Discussion Paper 192.

Huber, Evelyne, Huo, Jingjing, and Stephens, John D. (2016), 'Politics, Markets and Top Income Shares', 23rd International Conference of Europeanists (Philadelphia, April 2016).

Iversen, Torben and Soskice, David (2001), 'An Asset Theory of Social Policy Preferences', American Political Science Review, 95 (4), 875-93.

Iversen, Torben and Stephens, John D. (2008), 'Partisan Politics, the Welfare State, and Three Worlds of Human Capital Formation', Comparative Political Studies, 41 (4-5), 600-37.

Kakwani, Nanak C. (1977), 'Measurement of Tax Progressivity: An International Comparison', The Economic Journal, 87 (345), 71-80.

Katz, Lawrence F. and Krueger, Alan B. (1991), 'Changes in the Structure of Wages in the Public and Private Sectors', in Ronald Ehrenberg (ed.), Research in Labor Economics (12; Greenwich: JAI Press).

Katz, Lawrence F. and Murphy, Kevin M. (1992), 'Changes in Relative Wages, 1963-1987: Supply and Demand Factors', The Quarterly Journal of Economics, 107 (1), 35-78.

Katz, Lawrence F., Loveman, Gary W., and Blanchflower, David G. (1995), 'A Comparison of Changes in the Structure of Wages in Four OECD Countries', in Richard B. Freeman and Lawrence F. Katz (eds.), Differences and Changes in Wage Structures (Chicago: University of Chicago Press), 25-66.

Kumlin, Staffan and Stadelmann-Steffen, Isabelle (eds.) (2014), How Welfare States Shape the Democratic Public: Policy Feedback, Participation, Voting and Attitudes (Cheltenham: Edward Elgar).

LIS (2017), Luxembourg Income Study Database (Luxembourg: LIS, available at www.lisdatacenter.org (multiple countries, assessed on 2017-04-17)).

Lupu, Noam and Pontusson, Jonas (2011), 'The Structure of Inequality and the Politics of Redistribution', American Political Science Review, 105 (2), 316-36.

Mincer, Jabob A. (1974), Schooling, Experience, and Earnings (New York: NBER).

Moene, Karl Ove and Wallerstein, Michael (2001), 'Inequality, Social Insurance, and Redistribution', American Political Science Review, 95 (4), 859-74.

Murphy, Kevin M. and Welch, Finis (1992), 'The Structure of Wages', The Quarterly Journal of Economics, 107 (1), 285-326.

Nickell, Stephen (1981), 'Biases in Dynamic Models with Fixed Effects', Econometrica, 49 (6), 1417-26.

OECD (2011), Divided We Stand. Why Inequality Keeps Rising (Paris: OECD).

--- (2012), Taxing Wages 2011 (Paris: OECD).

--- (2016), OECD Education Statistics (http://dx.doi.org/10.1787/data-00211-en (Download 2016-11-11)).

--- (2017), OECD Tax Statistics (Paris: OECD).

Oesch, Daniel (2010), 'What explains high unemployment among low-skilled workers? Evidence from 21 OECD countries', European Journal of Industrial Relations, 16 (1), 39-55.

Pierson, Paul (1993), 'When Effect Becomes Cause: Policy Feedback and Political Change', World Politics, 45 (4), 595-628.

Piketty, Thomas and Saez, Emmanuel (2014), 'Inequality in the long run', Science, 344 (6186), 838-43.

Pontusson, Jonas and Weisstanner, David (2018), 'Macroeconomic conditions, inequality shocks and the politics of redistribution, 1990-2013', Journal of European Public Policy, 25 (1), 31-58. 
Pontusson, Jonas, Rueda, David, and Way, Christopher R. (2002), 'Comparative Political Economy of Wage Distribution: The Role of Partisanship and Labour Market Institutions', British Journal of Political Science, 32 (2), 281-308.

Rueda, David and Pontusson, Jonas (2000), 'Wage Inequality and Varieties of Capitalism', World Politics, 52 (3), 350-83.

Scharpf, Fritz W. (2000), 'Economic Changes, Vulnerabilities, and Institutional Capabilities', in Fritz W. Scharpf and Vivien A. Schmidt (eds.), Welfare and Work in the Open Economy. Vol. I. From Vulnerability to Competitiveness (Oxford: Oxford University Press), 21-124. --- (2001), 'Employment and the Welfare State: A Continental Dilemma?', in Bernhard Ebbinghaus and Philip Manow (eds.), Comparing Welfare Capitalism (London: Routledge), 270-83.

Tinbergen, Jan (1975), Income Distribution: Analysis and Policies (Amsterdam: North-Holland). van der Velden, Rolf and Bijlsma, Ineke (2016), 'College wage premiums and skills: a crosscountry analysis', Oxford Review of Economic Policy, 32 (4), 497-513.

Wallerstein, Michael (1999), 'Wage-Setting Institutions and Pay Inequality in Advanced Industrial Societies', American Journal of Political Science, 43 (3), 649-80. 
Table 1: Education premiums in 22 countries

\begin{tabular}{|c|c|c|c|c|c|}
\hline & 1995 & 2007 & 2013 & $\Delta 1995-2007$ & $\Delta 2007-13$ \\
\hline Australia & 0.36 [1995] & 0.31 [2008] & 0.41 [2010] & $-15 \%$ & $+33 \%$ \\
\hline Canada & 0.45 [1994] & 0.47 [2007] & 0.46 [2010] & $+4 \%$ & $-1 \%$ \\
\hline Ireland & 0.45 [1995] & 0.46 [2007] & 0.42 [2010] & $+2 \%$ & $-9 \%$ \\
\hline United Kingdom & 0.50 [1995] & 0.43 [2007] & $0.40 \quad$ [2013] & $-13 \%$ & $-7 \%$ \\
\hline United States & 0.59 [1994] & 0.61 [2007] & 0.67 [2013] & $+4 \%$ & $+9 \%$ \\
\hline Austria & 0.37 [1994] & 0.46 [2007] & 0.44 [2013] & $+25 \%$ & $-5 \%$ \\
\hline Belgium & 0.27 [1995] & 0.28 [2000] & & $+3 \%$ & \\
\hline France & 0.50 [1994] & 0.40 [2005] & 0.37 [2010] & $-20 \%$ & $-7 \%$ \\
\hline Germany & 0.31 [1994] & 0.41 [2007] & 0.46 [2013] & $+33 \%$ & $+11 \%$ \\
\hline Luxembourg & 0.82 [1994] & 0.69 [2007] & 0.90 [2013] & $-17 \%$ & $+31 \%$ \\
\hline Netherlands & 0.26 [1993] & 0.33 [2007] & 0.34 [2013] & $+25 \%$ & $+5 \%$ \\
\hline Switzerland & 0.35 [1992] & 0.43 [2007] & 0.41 [2013] & $+20 \%$ & $-4 \%$ \\
\hline Denmark & 0.22 [1995] & 0.19 [2007] & 0.22 [2013] & $-11 \%$ & $+13 \%$ \\
\hline Finland & 0.31 [1995] & 0.32 [2007] & 0.31 [2013] & $+2 \%$ & $-3 \%$ \\
\hline Norway & 0.22 [1995] & 0.18 [2007] & 0.20 [2013] & $-15 \%$ & $+10 \%$ \\
\hline Sweden & 0.21 [1995] & 0.17 [2005] & & $-20 \%$ & \\
\hline Greece & 0.50 [1995] & 0.56 [2007] & 0.23 [2013] & $+11 \%$ & $-59 \%$ \\
\hline Italy & 0.53 [1995] & 0.27 [2008] & 0.27 [2014] & $-48 \%$ & $-0 \%$ \\
\hline Spain & 0.77 [1995] & 0.51 [2007] & 0.61 [2013] & $-33 \%$ & $+20 \%$ \\
\hline Czech Republic & $0.60 \quad[1996]$ & 0.50 [2007] & 0.44 [2013] & $-17 \%$ & $-13 \%$ \\
\hline Poland & 0.54 [1999] & 0.51 [2007] & 0.39 [2013] & $-5 \%$ & $-24 \%$ \\
\hline Slovakia & 0.44 [1992] & 0.31 [2007] & 0.26 [2013] & $-30 \%$ & $-18 \%$ \\
\hline Average & 0.46 & 0.42 & 0.41 & $-8 \%$ & $-2 \%$ \\
\hline
\end{tabular}

Note: Averages calculated without Belgium and Sweden (missing data in the late 2000s). Full dataset: see Table A1 in the online appendix.

Source: Luxembourg Income Study Database (LIS) (www.lisdatacenter.org, microdata accessed on April 17, 2017). 
Table 2: Effects of policy indicators in regressions of education premium levels

\begin{tabular}{|c|c|c|c|c|c|c|}
\hline \multirow[b]{2}{*}{ Policy coefficient } & \multicolumn{3}{|c|}{$\begin{array}{l}\text { Models without lagged } \\
\text { dependent variable }\end{array}$} & \multicolumn{3}{|c|}{$\begin{array}{l}\text { Models including lagged } \\
\text { dependent variable }\end{array}$} \\
\hline & $(\mathrm{SE})$ & $\mathrm{R}^{2}$ & $\Delta 1 \mathrm{sd}$ & $(\mathrm{SE})$ & $\mathrm{R}^{2}$ & $\Delta 1 \mathrm{sd}$ \\
\hline Public education spending & $-5.78(0.47)^{* * *}$ & 0.35 & -6.6 & $-0.82(0.48)^{*}$ & 0.81 & -4.9 \\
\hline Private education spending & $6.92(2.04)^{* * *}$ & 0.29 & +5.8 & $2.97(0.87)^{* * *}$ & 0.82 & +7.7 \\
\hline Average tax rate & $-0.43(0.14)^{* * *}$ & 0.15 & -3.2 & $-0.19(0.06)^{* * *}$ & 0.81 & -8.2 \\
\hline Non-elderly social spending & $-2.57(0.35)^{* * *}$ & 0.44 & -7.7 & $-0.52(0.24)^{* *}$ & 0.81 & -6.2 \\
\hline EPL regular contracts & $-4.77(1.45)^{* * *}$ & 0.19 & -4.1 & $-2.04(0.58)^{* * *}$ & 0.82 & -8.7 \\
\hline EPL temporary contracts & $-0.21(1.26)$ & 0.11 & -1.6 & $-0.96(0.50)^{*}$ & 0.81 & -7.3 \\
\hline Bargaining coverage rate & $-0.15(0.04)^{* * *}$ & 0.25 & -5.2 & $-0.05(0.02)^{* *}$ & 0.81 & -6.0 \\
\hline
\end{tabular}

Notes: * $p<0.1$; ** $p<0.05$; *** $p<0.01$. N=92 (20 countries). Standard errors corrected for panel heteroscedasticity in parentheses and including panel-specific AR(1) error processes estimated with Prais-Winsten transformation. Control variables included: changes in tertiary education share, trade openness, factor productivity and unemployment, as well as LIS wave dummies (full results: see Tables A2 and A3 in the online appendix). $\mathrm{R}^{2}$ based on models estimated without $\mathrm{AR}(1)$ error processes. $\Delta 1 \mathrm{sd}$ : marginal effect of a 1 standard deviation increase in policy on education premium levels, in percentage points (LDV models: long-run multipliers). 
Table 3: Fixed effects regressions of education premiums, 1997-2014

\begin{tabular}{|c|c|c|c|c|}
\hline \multicolumn{2}{|c|}{ Dependent variable: education premium } & \multicolumn{2}{|l|}{ changes } & \multirow{2}{*}{$\begin{array}{c}\text { levels } \\
4\end{array}$} \\
\hline & 1 & 2 & 3 & \\
\hline$\overline{\text { Education premium } \mathrm{t}-1}$ & & & & $\begin{array}{l}0.45^{* * *} \\
(0.09)\end{array}$ \\
\hline$\Delta$ Tertiary education share ${ }_{t}$ & $\begin{array}{l}-0.69 * * * \\
(0.21)\end{array}$ & $\begin{array}{l}-0.80 * * * \\
(0.23)\end{array}$ & $\begin{array}{l}-0.79 * * * \\
(0.20)\end{array}$ & $\begin{array}{l}-0.49^{* * * *} \\
(0.18)\end{array}$ \\
\hline$\Delta$ Trade openness $_{\mathrm{t}}$ & $\begin{array}{c}0.05 \\
(0.09)\end{array}$ & $\begin{array}{l}0.21^{* *} \\
(0.09)\end{array}$ & $\begin{array}{l}0.21 * * \\
(0.09)\end{array}$ & $\begin{array}{c}0.12 \\
(0.08)\end{array}$ \\
\hline$\Delta$ Factor productivity $\mathrm{t}$ & $\begin{array}{l}0.85^{* * *} \\
(0.22)\end{array}$ & $\begin{array}{l}1.01^{* * *} \\
(0.22)\end{array}$ & $\begin{array}{l}0.94^{* * *} \\
(0.18)\end{array}$ & $\begin{array}{l}1.01^{* * *} \\
(0.18)\end{array}$ \\
\hline$\Delta$ Unemployment $_{\mathrm{t}}$ & $\begin{array}{l}0.67^{* * *} \\
(0.23)\end{array}$ & $\begin{array}{l}0.90 * * * \\
(0.30)\end{array}$ & $\begin{array}{l}0.86^{* * *} \\
(0.23)\end{array}$ & $\begin{array}{l}0.45^{* *} \\
(0.21)\end{array}$ \\
\hline Public education spending ${ }_{t}$ & & $\begin{array}{l}-4.72 * * * \\
(1.80)\end{array}$ & $\begin{array}{l}-5.18^{* * * *} \\
(1.36)\end{array}$ & $\begin{array}{l}-4.10^{* * *} \\
(1.55)\end{array}$ \\
\hline Private education spending $\mathrm{t}$ & & $\begin{array}{l}-0.31 \\
(4.11)\end{array}$ & & \\
\hline Average tax rate $t$ & & $\begin{array}{l}-1.52^{* * *} \\
(0.47)\end{array}$ & $\begin{array}{l}-1.47 * * * \\
(0.39)\end{array}$ & $\begin{array}{l}-1.83^{* * *} \\
(0.45)\end{array}$ \\
\hline Non-elderly social spending t & & $\begin{array}{l}-0.28 \\
(0.79)\end{array}$ & & \\
\hline EPL regular contracts ${ }_{t}$ & & $\begin{array}{c}-10.18 \\
(7.53)\end{array}$ & & \\
\hline EPL temporary contracts $t$ & & $\begin{array}{c}0.65 \\
(1.69)\end{array}$ & & \\
\hline Bargaining coverage rate $t_{t}$ & & $\begin{array}{c}0.07 \\
(0.15)\end{array}$ & & \\
\hline$\overline{R^{2}}$ & 0.57 & 0.66 & 0.67 & 0.98 \\
\hline$N$ of observations [countries] & $92[20]$ & $92[20]$ & $92[20]$ & $92[20]$ \\
\hline LIS wave dummies & yes & yes & yes & yes \\
\hline Country dummies & yes & yes & yes & yes \\
\hline
\end{tabular}

Notes: * $p<0.1$; ** $p<0.05$; *** $p<0.01$. Country and LIS wave dummies included (not shown). Standard errors corrected for panel heteroskedasticity in parentheses. Panel-specific AR(1) error processes estimated with PraisWinsten transformation. 
Figure 1: A causal sequence

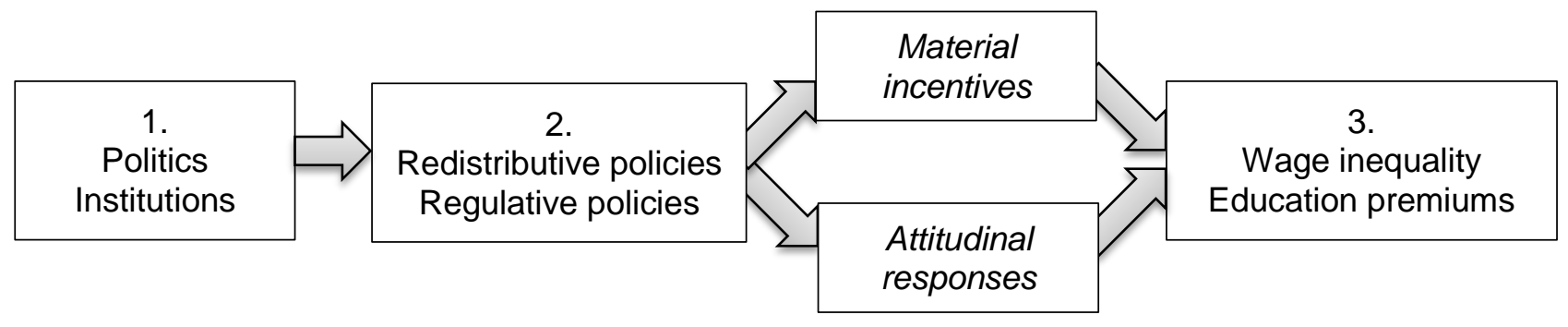

Figure 2: Attitudes towards returns on education and education premiums

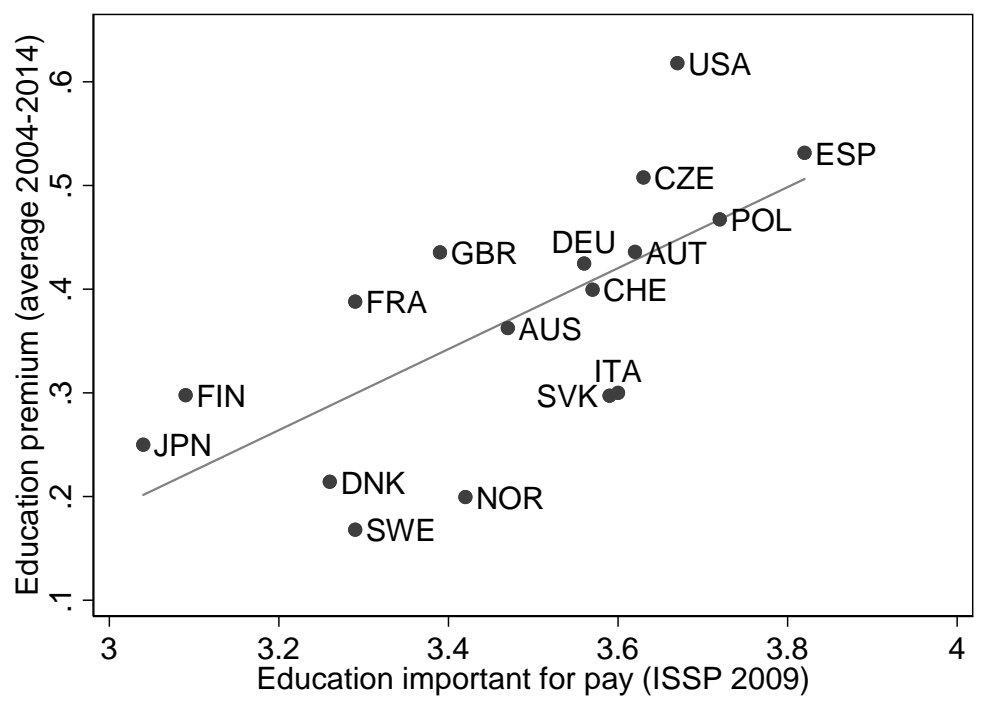

Sources: ISSP Social Inequality (2009), LIS microdata. 
Figure 3: Redistributive policies and attitudes towards returns on education
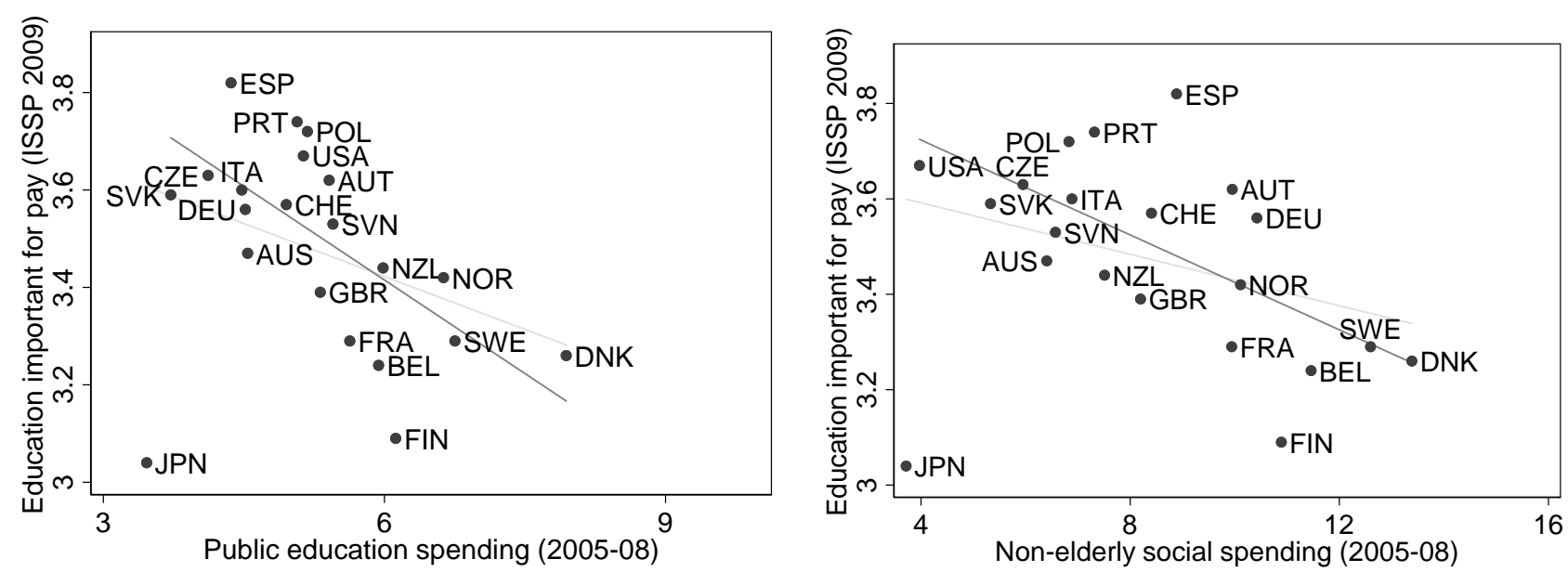

Note: Graphs include fitted lines (light grey: with Japan, dark grey: without Japan).

Sources: ISSP Social Inequality (2009), OECD (2016), Armingeon et al. (2016). 
Table A1: Full dataset of education premiums in 22 countries, 1989-2014

\begin{tabular}{|c|c|c|c|c|c|c|c|c|c|c|}
\hline Country & Premium & [year] & & & & & & & & \\
\hline Australia & 0.36 [89] & $0.36[95]$ & $0.41[01]$ & $0.40[03]$ & $0.31[08]$ & $0.41[10]$ & & & & \\
\hline Canada & $0.48[91]$ & $0.45[94]$ & $0.41[97]$ & $0.47[00]$ & $0.42[04]$ & $0.47[07]$ & $0.46[10]$ & & & \\
\hline Ireland & $0.49[94]$ & $0.45[95]$ & $0.31[96]$ & $0.36[00]$ & $0.49[04]$ & $0.46[07]$ & $0.42[10]$ & & & \\
\hline United Kingdom & $0.42[91]$ & $0.66[94]$ & $0.50[95]$ & 0.51 [99] & $0.49[04]$ & $0.43[07]$ & $0.41[10]$ & $0.40[13]$ & & \\
\hline United States & $0.58[91]$ & 0.59 [94] & 0.55 [97] & $0.62[00]$ & $0.57[04]$ & $0.61[07]$ & $0.63[10]$ & $0.67[13]$ & & \\
\hline Austria & 0.37 [94] & 0.37 [97] & $0.33[00]$ & $0.41[04]$ & $0.46[07]$ & $0.43[10]$ & $0.44[13]$ & & & \\
\hline Belgium & 0.33 [92] & 0.27 [95] & 0.27 [97] & $0.28[00]$ & & & & & & \\
\hline France & $0.51[89]$ & $0.50[94]$ & $0.49[00]$ & $0.40[05]$ & $0.37[10]$ & & & & & \\
\hline Germany & 0.42 [89] & 0.31 [94] & $0.37[00]$ & $0.38[04]$ & $0.41[07]$ & $0.45[10]$ & $0.46[13]$ & & & \\
\hline Luxembourg & $0.80[91]$ & $0.82[94]$ & $0.75[97]$ & $0.76[00]$ & $0.72[04]$ & $0.69[07]$ & $0.89[10]$ & $0.90[13]$ & & \\
\hline Netherlands & $0.27[90]$ & 0.26 [93] & 0.23 [99] & $0.30[04]$ & 0.33 [07] & $0.34[10]$ & $0.34[13]$ & & & \\
\hline Switzerland & $0.35[92]$ & $0.42[00]$ & $0.41[02]$ & $0.35[04]$ & $0.43[07]$ & $0.41[10]$ & $0.41[13]$ & & & \\
\hline Denmark & 0.23 [92] & 0.22 [95] & $0.22[00]$ & $0.22[04]$ & 0.19 [07] & $0.23[10]$ & $0.22[13]$ & & & \\
\hline Finland & $0.31[95]$ & $0.27[00]$ & $0.27[04]$ & $0.32[07]$ & $0.29[10]$ & $0.31[13]$ & & & & \\
\hline Norway & $0.27[91]$ & 0.22 [95] & $0.18[00]$ & $0.21[04]$ & $0.18[07]$ & $0.20[10]$ & $0.20[13]$ & & & \\
\hline Sweden & $0.27[92]$ & $0.21[95]$ & $0.19[00]$ & $0.17[05]$ & & & & & & \\
\hline Greece & $0.50[95]$ & $0.64[00]$ & $0.53[04]$ & 0.56 [07] & $0.29[10]$ & 0.23 [13] & & & & \\
\hline Italy & 0.24 [89] & $0.41[91]$ & 0.44 [93] & $0.53[95]$ & $0.29[98]$ & $0.25[00]$ & $0.38[04]$ & $0.27[08]$ & $0.28[10]$ & $0.27[14]$ \\
\hline Spain & $0.77[95]$ & $0.62[00]$ & $0.52[04]$ & $0.51[07]$ & $0.49[10]$ & $0.61[13]$ & & & & \\
\hline Czech Republic & $0.43[92]$ & $0.60[96]$ & $0.57[02]$ & $0.61[04]$ & $0.50[07]$ & $0.48[10]$ & $0.44[13]$ & & & \\
\hline Poland & 0.54 [99] & $0.51[07]$ & $0.50[10]$ & 0.39 [13] & & & & & & \\
\hline Slovakia & $0.44[92]$ & $0.31[04]$ & $0.31[07]$ & $0.31[10]$ & $0.26[13]$ & & & & & \\
\hline
\end{tabular}

Note: values in italics estimated with changes from net income data. Source: LIS microdata. 
Table A2: OLS regressions of education premium levels, models without lagged dependent variable

\begin{tabular}{|c|c|c|c|c|c|c|c|}
\hline DV: Education premium ${ }_{t}$ & A1 & A2 & A3 & A4 & A5 & A6 & A7 \\
\hline$\Delta$ Tertiary education share $t$ & $\begin{array}{l}-0.45^{*} \\
(0.24)\end{array}$ & $\begin{array}{l}-0.24 \\
(0.22)\end{array}$ & $\begin{array}{l}-0.40^{*} \\
(0.23)\end{array}$ & $\begin{array}{l}-0.34^{*} \\
(0.20)\end{array}$ & $\begin{array}{l}-0.32 \\
(0.23)\end{array}$ & $\begin{array}{l}-0.28 \\
(0.23)\end{array}$ & $\begin{array}{l}-0.28 \\
(0.24)\end{array}$ \\
\hline$\Delta$ Trade openness ${ }_{t}$ & $\begin{array}{l}-0.00 \\
(0.10)\end{array}$ & $\begin{array}{l}-0.07 \\
(0.07)\end{array}$ & $\begin{array}{l}-0.05 \\
(0.09)\end{array}$ & $\begin{array}{l}-0.02 \\
(0.08)\end{array}$ & $\begin{array}{l}-0.05 \\
(0.08)\end{array}$ & $\begin{array}{l}-0.07 \\
(0.09)\end{array}$ & $\begin{array}{l}-0.10 \\
(0.08)\end{array}$ \\
\hline$\Delta$ Factor productivity $\mathrm{t}$ & $\begin{array}{l}0.74^{* * *} \\
(0.27)\end{array}$ & $\begin{array}{l}0.98^{* * *} \\
(0.26)\end{array}$ & $\begin{array}{l}0.80^{* * *} \\
(0.26)\end{array}$ & $\begin{array}{l}0.78^{* * *} \\
(0.22)\end{array}$ & $\begin{array}{l}0.89 * * * \\
(0.27)\end{array}$ & $\begin{array}{l}0.77 * * * \\
(0.27)\end{array}$ & $\begin{array}{l}0.70^{* * *} \\
(0.27)\end{array}$ \\
\hline$\Delta$ Unemployment $_{\mathrm{t}}$ & $\begin{array}{c}0.21 \\
(0.34)\end{array}$ & $\begin{array}{c}0.27 \\
(0.37)\end{array}$ & $\begin{array}{c}0.24 \\
(0.35)\end{array}$ & $\begin{array}{c}0.44 \\
(0.36)\end{array}$ & $\begin{array}{c}0.20 \\
(0.37)\end{array}$ & $\begin{array}{c}0.14 \\
(0.36)\end{array}$ & $\begin{array}{c}0.27 \\
(0.44)\end{array}$ \\
\hline Public education spending $\mathrm{t}$ & $\begin{array}{l}-5.78 * * * \\
(0.47)\end{array}$ & & & & & & \\
\hline Private education spending $\mathrm{t}$ & & $\begin{array}{l}6.92^{* * *} \\
(2.04)\end{array}$ & & & & & \\
\hline Average tax rate ${ }_{t}$ & & & $\begin{array}{l}-0.38 * * * \\
(0.13)\end{array}$ & & & & \\
\hline Non-elderly social spending t & & & & $\begin{array}{l}-2.57 * * * \\
(0.35)\end{array}$ & & & \\
\hline EPL regular contracts $t$ & & & & & $\begin{array}{l}-4.77 * * * \\
(1.45)\end{array}$ & & \\
\hline EPL temporary contracts ${ }_{t}$ & & & & & & $\begin{array}{l}-0.21 \\
(1.26)\end{array}$ & \\
\hline Bargaining coverage rate ${ }_{t}$ & & & & & & & $\begin{array}{l}-0.15^{* * *} \\
(0.04)\end{array}$ \\
\hline$R^{2}$ & 0.88 & 0.86 & 0.87 & 0.94 & 0.91 & 0.91 & 0.92 \\
\hline$R^{2}$ without AR(1) processes & 0.35 & 0.29 & 0.16 & 0.44 & 0.19 & 0.11 & 0.25 \\
\hline$N$ of observations [countries] & $92[20]$ & $92[20]$ & $92[20]$ & 92 [20] & $92[20]$ & $92[20]$ & $92[20]$ \\
\hline LIS wave dummies & yes & yes & yes & yes & yes & yes & yes \\
\hline Country dummies & no & no & no & no & no & no & no \\
\hline
\end{tabular}

Notes: $* p<0.1$; ** $p<0.05$; *** $p<0.01$. LIS wave dummies included (not shown). Standard errors corrected for panel heteroskedasticity in parentheses. Panel-specific AR(1) error processes estimated with Prais-Winsten transformation. 
Table A3: OLS regressions of education premium levels, models including lagged dependent variable

\begin{tabular}{|c|c|c|c|c|c|c|c|}
\hline DV: Education premium ${ }_{t}$ & A8 & A9 & A10 & A11 & A12 & A13 & A14 \\
\hline$\overline{\text { Education premium }} \mathrm{t}-1$ & $\begin{array}{l}0.77^{* * *} \\
(0.05)\end{array}$ & $\begin{array}{l}0.78^{* * *} \\
(0.03)\end{array}$ & $\begin{array}{l}0.81^{* * *} \\
(0.03)\end{array}$ & $\begin{array}{l}0.76^{* * *} \\
(0.04)\end{array}$ & $\begin{array}{l}0.80 * * * \\
(0.03)\end{array}$ & $\begin{array}{l}0.83^{* * *} \\
(0.03)\end{array}$ & $\begin{array}{l}0.80^{* * *} \\
(0.04)\end{array}$ \\
\hline$\Delta$ Tertiary education share $t$ & $\begin{array}{l}-0.36^{*} \\
(0.20)\end{array}$ & $\begin{array}{l}-0.37 * * \\
(0.18)\end{array}$ & $\begin{array}{l}-0.59 * * * \\
(0.19)\end{array}$ & $\begin{array}{l}-0.40 * * \\
(0.20)\end{array}$ & $\begin{array}{l}-0.50 * * * \\
(0.19)\end{array}$ & $\begin{array}{l}-0.42^{* *} \\
(0.20)\end{array}$ & $\begin{array}{l}-0.45^{* *} \\
(0.20)\end{array}$ \\
\hline$\Delta$ Trade openness $_{\mathrm{t}}$ & $\begin{array}{l}-0.10 \\
(0.07)\end{array}$ & $\begin{array}{l}-0.05 \\
(0.07)\end{array}$ & $\begin{array}{l}-0.06 \\
(0.07)\end{array}$ & $\begin{array}{l}-0.08 \\
(0.07)\end{array}$ & $\begin{array}{l}-0.02 \\
(0.08)\end{array}$ & $\begin{array}{l}-0.09 \\
(0.07)\end{array}$ & $\begin{array}{l}-0.09 \\
(0.07)\end{array}$ \\
\hline$\Delta$ Factor productivity ${ }_{\mathrm{t}}$ & $\begin{array}{l}0.57 * * * \\
(0.14)\end{array}$ & $\begin{array}{l}0.54^{* * *} \\
(0.14)\end{array}$ & $\begin{array}{l}0.57 * * * \\
(0.13)\end{array}$ & $\begin{array}{l}0.57 * * * \\
(0.14)\end{array}$ & $\begin{array}{l}0.56^{* * *} \\
(0.14)\end{array}$ & $\begin{array}{l}0.49 * * * \\
(0.16)\end{array}$ & $\begin{array}{l}0.51^{* * *} \\
(0.15)\end{array}$ \\
\hline$\Delta$ Unemployment $_{\mathrm{t}}$ & $\begin{array}{l}0.54^{* *} \\
(0.24)\end{array}$ & $\begin{array}{l}0.62^{* * *} \\
(0.22)\end{array}$ & $\begin{array}{l}0.60 * * * \\
(0.22)\end{array}$ & $\begin{array}{l}0.68 * * * \\
(0.25)\end{array}$ & $\begin{array}{l}0.62 * * * \\
(0.22)\end{array}$ & $\begin{array}{l}0.61^{* * *} \\
(0.24)\end{array}$ & $\begin{array}{l}0.65^{* * *} \\
(0.24)\end{array}$ \\
\hline Public education spending $t$ & $\begin{array}{l}-0.82 * \\
(0.48)\end{array}$ & & & & & & \\
\hline Private education spending $\mathrm{t}$ & & $\begin{array}{l}2.97 * * * \\
(0.87)\end{array}$ & & & & & \\
\hline Average tax rate ${ }_{t}$ & & & $\begin{array}{l}-0.20 * * * \\
(0.06)\end{array}$ & & & & \\
\hline Non-elderly social spending $t$ & & & & $\begin{array}{l}-0.52 * * \\
(0.24)\end{array}$ & & & \\
\hline EPL regular contracts ${ }_{t}$ & & & & & $\begin{array}{l}-2.04 * * * \\
(0.58)\end{array}$ & & \\
\hline EPL temporary contracts ${ }_{t}$ & & & & & & $\begin{array}{l}-0.96^{*} \\
(0.50)\end{array}$ & \\
\hline Bargaining coverage rate $_{t}$ & & & & & & & $\begin{array}{l}-0.05^{* *} \\
(0.02)\end{array}$ \\
\hline$\overline{R^{2}}$ & 0.95 & 0.97 & 0.97 & 0.96 & 0.97 & 0.97 & 0.97 \\
\hline$R^{2}$ without $\mathrm{AR}(1)$ processes & 0.81 & 0.82 & 0.82 & 0.81 & 0.82 & 0.81 & 0.81 \\
\hline$N$ of observations [countries] & $92[20]$ & $92[20]$ & $92[20]$ & $92[20]$ & $92[20]$ & $92[20]$ & $92[20]$ \\
\hline LIS wave dummies & yes & yes & yes & yes & yes & yes & yes \\
\hline Country dummies & no & no & no & no & no & no & no \\
\hline
\end{tabular}

Notes: ${ }^{*} p<0.1 ; * * p<0.05 ; * * * p<0.01$. LIS wave dummies included (not shown). Standard errors corrected for panel heteroskedasticity in parentheses. Panel-specific AR(1) error processes estimated with Prais-Winsten transformation. 
The following Table A4 provides a summary of the results from various error correction models (ECM). The full results are subsequently presented in Tables A5, A6 and A7.

Table A4 displays the total long-run effects (long-run multipliers) for four types of model specifications:

- First column: ECM models without fixed effects, where we estimate separate models for each policy due to multicollinearity concerns.

- Second column: Separate ECM models for each policy, including country fixed effects.

- Third column: A fixed-effects ECM model including all seven policies within the same model. Note in Table A7 that the number of observations in this specification drops from 92 to 74 due to missing values on the lagged policy indicators.

- Fourth column: A fixed-effects ECM model including six policies within the same model, but excluding private education spending. Private education spending is responsible for a considerable part of missing values in the ECM models. Excluding private education increases the number of observations.

Table A4: Total long-run effects (long-run multipliers) from error correction models of education premium changes

\begin{tabular}{lcccc}
\hline & No fixed effects & Fixed effects & Fixed effects & Fixed effects \\
\hline & 1 policy at a time & 1 policy at a time & All 7 policies & $\begin{array}{c}\text { All policies excl. } \\
\text { private education } \\
\text { spending }\end{array}$ \\
\hline Policy indicator & $-7.16(0.47)^{* * *}$ & $-12.99(2.81)^{* * *}$ & $-8.80(3.29)^{* * *}$ & $-8.10(2.75)^{* * *}$ \\
Public education spending & $14.98(0.96)^{* * *}$ & $-0.34(3.17)$ & $6.04(4.25)$ & \\
Private education spending & $-0.77(0.07)^{* * *}$ & $-2.58(0.42)^{* * *}$ & $-2.03(0.85)^{* *}$ & $-2.23(0.50)^{* * *}$ \\
Average tax rate & $-2.65(0.16)^{* * *}$ & $-4.55(0.76)^{* * *}$ & $-2.47(1.03)^{* *}$ & $-1.99(0.74)^{* * *}$ \\
Non-elderly social spending & $-13.03(0.71)^{* * *}$ & $-5.44(7.53)$ & $-11.91(11.45)$ & $-19.56(9.63)^{* *}$ \\
EPL regular contracts & $-8.29(0.56)^{* * *}$ & $8.07(1.69)^{* * *}$ & $-5.31(2.49)^{* *}$ & $-2.60(1.37)^{*}$ \\
EPL temporary contracts & $-0.25(0.02)^{* * *}$ & $0.69(0.16)^{* * *}$ & $-0.52(0.21)^{* *}$ & $0.16(0.20)$ \\
Bargaining coverage rate & yes & yes & yes & yes \\
\hline LIS wave dummies & no & yes & yes & yes \\
Country dummies & Table A5 & Table A6 & Table A7 & Table A7 \\
Full results & & & &
\end{tabular}

Notes: * $p<0.1$; ** $p<0.05$; *** $p<0.01$. Full regression results: see Tables A5, A6 and A7. Standard error of the long-run multipliers estimated with Bewley transformation. 
Table A5: Error correction models of education premium changes, no fixed effects, one policy at a time

\begin{tabular}{|c|c|c|c|c|c|c|c|}
\hline DV: $\Delta$ Education premium $\mathrm{t}$ & A15 & A16 & A17 & A18 & A19 & A20 & A21 \\
\hline$\overline{\text { Education premium } \mathrm{t}-1}$ & $\begin{array}{l}-0.23^{* * *} \\
(0.05)\end{array}$ & $\begin{array}{l}-0.30^{* * *} \\
(0.06)\end{array}$ & $\begin{array}{l}-0.15^{* * *} \\
(0.04)\end{array}$ & $\begin{array}{l}-0.28 * * * \\
(0.05)\end{array}$ & $\begin{array}{l}-0.17^{* * *} \\
(0.05)\end{array}$ & $\begin{array}{l}-0.12^{* * *} \\
(0.04)\end{array}$ & $\begin{array}{l}-0.17 * * * \\
(0.05)\end{array}$ \\
\hline$\Delta$ Tertiary education share $\mathrm{t}$ & $\begin{array}{l}-0.47^{* *} \\
(0.20)\end{array}$ & $\begin{array}{l}-0.27 \\
(0.20)\end{array}$ & $\begin{array}{l}-0.50^{* *} \\
(0.20)\end{array}$ & $\begin{array}{l}-0.48 * * * \\
(0.18)\end{array}$ & $\begin{array}{l}-0.38 * \\
(0.20)\end{array}$ & $\begin{array}{l}-0.39 * \\
(0.22)\end{array}$ & $\begin{array}{l}-0.44^{* *} \\
(0.20)\end{array}$ \\
\hline Tertiary education share $\mathrm{t}-1$ & $\begin{array}{l}0.12^{* *} \\
(0.06)\end{array}$ & $\begin{array}{c}0.06 \\
(0.05)\end{array}$ & $\begin{array}{c}0.03 \\
(0.05)\end{array}$ & $\begin{array}{l}0.14^{* * *} \\
(0.05)\end{array}$ & $\begin{array}{l}-0.01 \\
(0.05)\end{array}$ & $\begin{array}{c}0.06 \\
(0.04)\end{array}$ & $\begin{array}{c}0.06 \\
(0.05)\end{array}$ \\
\hline$\Delta$ Trade openness $\mathrm{t}_{\mathrm{t}}$ & $\begin{array}{l}-0.01 \\
(0.08)\end{array}$ & $\begin{array}{l}-0.04 \\
(0.08)\end{array}$ & $\begin{array}{l}-0.03 \\
(0.08)\end{array}$ & $\begin{array}{l}-0.04 \\
(0.07)\end{array}$ & $\begin{array}{c}0.01 \\
(0.07)\end{array}$ & $\begin{array}{l}-0.01 \\
(0.09)\end{array}$ & $\begin{array}{l}-0.07 \\
(0.09)\end{array}$ \\
\hline Trade openness $t-1$ & $\begin{array}{l}-0.01 \\
(0.02)\end{array}$ & $\begin{array}{c}0.03 \\
(0.02)\end{array}$ & $\begin{array}{l}-0.01 \\
(0.01)\end{array}$ & $\begin{array}{c}0.01 \\
(0.01)\end{array}$ & $\begin{array}{c}0.03 \\
(0.02)\end{array}$ & $\begin{array}{l}-0.01 \\
(0.01)\end{array}$ & $\begin{array}{c}0.00 \\
(0.02)\end{array}$ \\
\hline$\Delta$ Factor productivity $\mathrm{t}$ & $\begin{array}{l}0.62^{* *} \\
(0.26)\end{array}$ & $\begin{array}{c}0.56^{*} \\
(0.32)\end{array}$ & $\begin{array}{l}0.46^{* *} \\
(0.23)\end{array}$ & $\begin{array}{l}0.60^{* *} \\
(0.25)\end{array}$ & $\begin{array}{c}0.31 \\
(0.20)\end{array}$ & $\begin{array}{c}0.50^{*} \\
(0.27)\end{array}$ & $\begin{array}{c}0.35 \\
(0.23)\end{array}$ \\
\hline Factor productivity t-1 & $\begin{array}{c}0.02 \\
(0.12)\end{array}$ & $\begin{array}{c}0.00 \\
(0.15)\end{array}$ & $\begin{array}{l}-0.03 \\
(0.09)\end{array}$ & $\begin{array}{l}-0.04 \\
(0.09)\end{array}$ & $\begin{array}{l}-0.04 \\
(0.09)\end{array}$ & $\begin{array}{l}-0.00 \\
(0.10)\end{array}$ & $\begin{array}{l}-0.06 \\
(0.09)\end{array}$ \\
\hline$\Delta$ Unemployment $_{\mathrm{t}}$ & $\begin{array}{c}0.33 \\
(0.25)\end{array}$ & $\begin{array}{c}0.44 \\
(0.29)\end{array}$ & $\begin{array}{l}0.61^{* *} \\
(0.26)\end{array}$ & $\begin{array}{c}0.46 \\
(0.29)\end{array}$ & $\begin{array}{l}0.65^{* * *} \\
(0.22)\end{array}$ & $\begin{array}{c}0.50 * \\
(0.26)\end{array}$ & $\begin{array}{l}0.65^{* * *} \\
(0.23)\end{array}$ \\
\hline Unemployment $\mathrm{t}-1$ & $\begin{array}{l}-0.21 \\
(0.19)\end{array}$ & $\begin{array}{c}0.16 \\
(0.21)\end{array}$ & $\begin{array}{l}-0.22 \\
(0.17)\end{array}$ & $\begin{array}{c}0.02 \\
(0.19)\end{array}$ & $\begin{array}{c}0.09 \\
(0.17)\end{array}$ & $\begin{array}{l}-0.18 \\
(0.20)\end{array}$ & $\begin{array}{l}-0.03 \\
(0.20)\end{array}$ \\
\hline$\Delta$ Public education spending $\mathrm{t}_{\mathrm{t}}$ & $\begin{array}{c}1.59 \\
(1.98)\end{array}$ & & & & & & \\
\hline Public education spending $\mathrm{t}-1$ & $\begin{array}{l}-1.63^{* * *} \\
(0.59)\end{array}$ & & & & & & \\
\hline$\Delta$ Private education spending $\mathrm{t}$ & & $\begin{array}{c}1.06 \\
(3.23)\end{array}$ & & & & & \\
\hline Private education spending t-1 & & $\begin{array}{l}4.47^{* * *} \\
(1.23)\end{array}$ & & & & & \\
\hline$\Delta$ Average tax rate $t$ & & & $\begin{array}{l}-0.65 * \\
(0.38)\end{array}$ & & & & \\
\hline Average tax rate $\mathrm{t}-1$ & & & $\begin{array}{l}-0.11 \\
(0.08)\end{array}$ & & & & \\
\hline$\Delta$ Non-elderly social spending $\mathrm{t}$ & & & & $\begin{array}{c}0.39 \\
(0.68)\end{array}$ & & & \\
\hline Non-elderly social spending t-1 & & & & $\begin{array}{l}-0.75^{* * *} \\
(0.25)\end{array}$ & & & \\
\hline$\Delta$ EPL regular contracts ${ }_{t}$ & & & & & $\begin{array}{c}7.52 \\
(5.49)\end{array}$ & & \\
\hline EPL regular contracts $t-1$ & & & & & $\begin{array}{l}-2.17^{* *} \\
(0.87)\end{array}$ & & \\
\hline$\Delta$ EPL temporary contracts $\mathrm{t}$ & & & & & & $\begin{array}{l}-5.21 * * \\
(2.61)\end{array}$ & \\
\hline EPL temporary contracts $t-1$ & & & & & & $\begin{array}{l}-1.02 * \\
(0.60)\end{array}$ & \\
\hline$\Delta$ Bargaining coverage rate $t_{t}$ & & & & & & & $\begin{array}{c}0.19 \\
(0.16)\end{array}$ \\
\hline Bargaining coverage rate $\mathrm{t}-1$ & & & & & & & $\begin{array}{l}-0.04^{*} \\
(0.02)\end{array}$ \\
\hline$\overline{R^{2}}$ & 0.42 & 0.46 & 0.43 & 0.46 & 0.47 & 0.43 & 0.43 \\
\hline$R^{2}$ without $\mathrm{AR}(1)$ processes & 0.28 & 0.33 & 0.25 & 0.29 & 0.28 & 0.26 & 0.25 \\
\hline$N$ of observations [countries] & $87[20]$ & $75[20]$ & $90[20]$ & $92[20]$ & $92[20]$ & $92[20]$ & $90[20]$ \\
\hline LIS wave dummies & yes & yes & yes & yes & yes & yes & yes \\
\hline Country dummies & no & no & no & no & no & no & no \\
\hline
\end{tabular}

Notes: $* p<0.1$; ** $p<0.05$; *** $p<0.01$. LIS wave dummies included (not shown). Standard errors corrected for panel heteroskedasticity in parentheses. Panel-specific AR(1) error processes estimated with Prais-Winsten transformation. 
Table A6: Error correction models of education premium changes, with fixed effects, one policy at a time

\begin{tabular}{|c|c|c|c|c|c|c|c|}
\hline DV: $\Delta$ Education premium $\mathrm{t}$ & A22 & A23 & A24 & A25 & A26 & A27 & A28 \\
\hline$\overline{\text { Education premium } \mathrm{t}-1}$ & $\begin{array}{l}-0.59 * * * \\
(0.10)\end{array}$ & $\begin{array}{l}-0.69 * * * \\
(0.09)\end{array}$ & $\begin{array}{l}-0.66^{* * *} \\
(0.11)\end{array}$ & $\begin{array}{l}-0.66^{* * *} \\
(0.09)\end{array}$ & $\begin{array}{l}-0.47^{* * *} \\
(0.11)\end{array}$ & $\begin{array}{l}-0.48^{* * *} \\
(0.09)\end{array}$ & $\begin{array}{l}-0.72 * * * \\
(0.10)\end{array}$ \\
\hline$\Delta$ Tertiary education share $\mathrm{t}$ & $\begin{array}{l}-0.26 \\
(0.18)\end{array}$ & $\begin{array}{l}-0.26 \\
(0.22)\end{array}$ & $\begin{array}{l}-0.61^{* * *} \\
(0.23)\end{array}$ & $\begin{array}{l}-0.27 \\
(0.18)\end{array}$ & $\begin{array}{l}-0.34 \\
(0.23)\end{array}$ & $\begin{array}{l}-0.30 \\
(0.19)\end{array}$ & $\begin{array}{l}-0.60 * * * \\
(0.22)\end{array}$ \\
\hline Tertiary education share $\mathrm{t}-1$ & $\begin{array}{l}-0.15 \\
(0.21)\end{array}$ & $\begin{array}{l}-0.04 \\
(0.22)\end{array}$ & $\begin{array}{l}-0.38 * \\
(0.20)\end{array}$ & $\begin{array}{l}-0.04 \\
(0.19)\end{array}$ & $\begin{array}{l}-0.21 \\
(0.22)\end{array}$ & $\begin{array}{l}-0.36 * \\
(0.19)\end{array}$ & $\begin{array}{l}-0.42 * \\
(0.23)\end{array}$ \\
\hline$\Delta$ Trade openness $\mathrm{t}_{\mathrm{t}}$ & $\begin{array}{l}0.29 * * \\
(0.12)\end{array}$ & $\begin{array}{c}0.11 \\
(0.10)\end{array}$ & $\begin{array}{c}0.10 \\
(0.09)\end{array}$ & $\begin{array}{c}0.02 \\
(0.08)\end{array}$ & $\begin{array}{c}0.05 \\
(0.10)\end{array}$ & $\begin{array}{c}0.05 \\
(0.09)\end{array}$ & $\begin{array}{c}0.12 \\
(0.09)\end{array}$ \\
\hline Trade openness $t-1$ & $\begin{array}{l}0.25^{* * *} \\
(0.09)\end{array}$ & $\begin{array}{c}0.09 \\
(0.08)\end{array}$ & $\begin{array}{c}0.13 \\
(0.10)\end{array}$ & $\begin{array}{c}0.02 \\
(0.07)\end{array}$ & $\begin{array}{c}0.15^{*} \\
(0.08)\end{array}$ & $\begin{array}{l}0.22^{* * *} \\
(0.08)\end{array}$ & $\begin{array}{l}0.25^{* * *} \\
(0.09)\end{array}$ \\
\hline$\Delta$ Factor productivity $\mathrm{t}$ & $\begin{array}{l}0.60^{* * *} \\
(0.23)\end{array}$ & $\begin{array}{l}1.03^{* * *} \\
(0.27)\end{array}$ & $\begin{array}{l}0.73^{* * *} \\
(0.21)\end{array}$ & $\begin{array}{l}1.03^{* * *} \\
(0.25)\end{array}$ & $\begin{array}{l}0.57^{* *} \\
(0.26)\end{array}$ & $\begin{array}{l}0.44^{* *} \\
(0.18)\end{array}$ & $\begin{array}{c}0.19 \\
(0.21)\end{array}$ \\
\hline Factor productivity t-1 & $\begin{array}{l}-0.06 \\
(0.13)\end{array}$ & $\begin{array}{c}0.02 \\
(0.13)\end{array}$ & $\begin{array}{l}-0.16^{*} \\
(0.10)\end{array}$ & $\begin{array}{l}-0.08 \\
(0.10)\end{array}$ & $\begin{array}{l}-0.16 \\
(0.10)\end{array}$ & $\begin{array}{l}-0.30 * * * \\
(0.09)\end{array}$ & $\begin{array}{l}-0.24^{* * *} \\
(0.09)\end{array}$ \\
\hline$\Delta$ Unemployment $_{\mathrm{t}}$ & $\begin{array}{c}0.41 \\
(0.26)\end{array}$ & $\begin{array}{c}0.13 \\
(0.20)\end{array}$ & $\begin{array}{c}0.27 \\
(0.22)\end{array}$ & $\begin{array}{l}0.71^{* *} \\
(0.29)\end{array}$ & $\begin{array}{c}0.35 \\
(0.27)\end{array}$ & $\begin{array}{c}0.39 * \\
(0.24)\end{array}$ & $\begin{array}{c}0.33 \\
(0.24)\end{array}$ \\
\hline Unemployment $\mathrm{t}-1$ & $\begin{array}{c}0.43 \\
(0.37)\end{array}$ & $\begin{array}{c}0.58 * \\
(0.35)\end{array}$ & $\begin{array}{c}0.37 \\
(0.38)\end{array}$ & $\begin{array}{c}0.62 * \\
(0.37)\end{array}$ & $\begin{array}{c}0.01 \\
(0.42)\end{array}$ & $\begin{array}{l}-0.05 \\
(0.35)\end{array}$ & $\begin{array}{c}0.18 \\
(0.35)\end{array}$ \\
\hline$\Delta$ Public education spending $\mathrm{t}_{\mathrm{t}}$ & $\begin{array}{c}2.00 \\
(1.86)\end{array}$ & & & & & & \\
\hline Public education spending $\mathrm{t}-1$ & $\begin{array}{l}-7.63^{* * *} \\
(2.59)\end{array}$ & & & & & & \\
\hline$\Delta$ Private education spending $\mathrm{t}$ & & $\begin{array}{l}-1.40 \\
(3.30)\end{array}$ & & & & & \\
\hline Private education spending t-1 & & $\begin{array}{l}-0.23 \\
(3.18)\end{array}$ & & & & & \\
\hline$\Delta$ Average tax rate $t$ & & & $\begin{array}{l}-1.10^{* *} \\
(0.53)\end{array}$ & & & & \\
\hline Average tax rate $\mathrm{t}-1$ & & & $\begin{array}{l}-1.71^{* * *} \\
(0.44)\end{array}$ & & & & \\
\hline$\Delta$ Non-elderly social spending $\mathrm{t}$ & & & & $\begin{array}{l}-0.12 \\
(0.94)\end{array}$ & & & \\
\hline Non-elderly social spending t-1 & & & & $\begin{array}{l}-3.00 * * * \\
(0.76)\end{array}$ & & & \\
\hline$\Delta$ EPL regular contracts ${ }_{t}$ & & & & & $\begin{array}{c}2.35 \\
(8.84)\end{array}$ & & \\
\hline EPL regular contracts $t-1$ & & & & & $\begin{array}{l}-2.54 \\
(7.50)\end{array}$ & & \\
\hline$\Delta$ EPL temporary contracts $\mathrm{t}$ & & & & & & $\begin{array}{l}-2.54 \\
(2.95)\end{array}$ & \\
\hline EPL temporary contracts ${ }_{t-1}$ & & & & & & $\begin{array}{l}3.86^{* *} \\
(1.57)\end{array}$ & \\
\hline$\Delta$ Bargaining coverage rate $t_{t}$ & & & & & & & $\begin{array}{l}0.45^{* * *} \\
(0.15)\end{array}$ \\
\hline Bargaining coverage rate $\mathrm{t}-1$ & & & & & & & $\begin{array}{l}0.50^{* * *} \\
(0.15)\end{array}$ \\
\hline$\overline{R^{2}}$ & 0.71 & 0.80 & 0.72 & 0.71 & 0.61 & 0.69 & 0.69 \\
\hline$R^{2}$ without $\mathrm{AR}(1)$ processes & 0.62 & 0.72 & 0.63 & 0.61 & 0.54 & 0.58 & 0.62 \\
\hline$N$ of observations [countries] & $87[20]$ & $75[20]$ & $90[20]$ & $92[20]$ & $92[20]$ & $92[20]$ & $90[20]$ \\
\hline LIS wave dummies & yes & yes & yes & yes & yes & yes & yes \\
\hline Country dummies & yes & yes & yes & yes & yes & yes & yes \\
\hline
\end{tabular}

Notes: * $p<0.1$; ** $p<0.05$; *** $p<0.01$. LIS wave dummies included (not shown). Standard errors corrected for panel heteroskedasticity in parentheses. Panel-specific AR(1) error processes estimated with Prais-Winsten transformation. 
Table A7: Error correction models of education premium changes, with fixed effects, several policies

\begin{tabular}{|c|c|c|c|}
\hline DV: $\Delta$ Education premium ${ }_{\mathrm{t}}$ & A29 & A30 & A31 \\
\hline$\overline{\text { Education premium } \mathrm{t}-1}$ & $\begin{array}{l}-1.08^{* * *} \\
(0.09)\end{array}$ & $\begin{array}{l}-1.00^{* * *} \\
(0.10)\end{array}$ & $\begin{array}{l}-0.74^{* * *} \\
(0.11)\end{array}$ \\
\hline$\Delta$ Tertiary education share ${ }_{t}$ & $\begin{array}{l}-0.56^{* *} \\
(0.26)\end{array}$ & $\begin{array}{l}-0.76 * * * \\
(0.18)\end{array}$ & $\begin{array}{l}-0.65^{* * *} \\
(0.18)\end{array}$ \\
\hline Tertiary education share ${ }_{t-1}$ & $\begin{array}{l}-0.34 \\
(0.27)\end{array}$ & $\begin{array}{l}-0.44^{* *} \\
(0.17)\end{array}$ & $\begin{array}{l}-0.33^{*} \\
(0.17)\end{array}$ \\
\hline$\Delta$ Trade openness $t$ & $\begin{array}{l}0.35^{* * *} \\
(0.13)\end{array}$ & $\begin{array}{c}0.15 \\
(0.10)\end{array}$ & $\begin{array}{l}0.21^{* *} \\
(0.10)\end{array}$ \\
\hline Trade openness ${ }_{t-1}$ & $\begin{array}{c}0.05 \\
(0.14)\end{array}$ & $\begin{array}{l}-0.02 \\
(0.12)\end{array}$ & $\begin{array}{c}0.12 \\
(0.08)\end{array}$ \\
\hline$\Delta$ Factor productivity $_{\mathrm{t}}$ & $\begin{array}{l}1.34^{* * *} \\
(0.31)\end{array}$ & $\begin{array}{l}0.97^{* * *} \\
(0.31)\end{array}$ & $\begin{array}{l}0.83^{* * *} \\
(0.17)\end{array}$ \\
\hline Factor productivity t-1 & $\begin{array}{l}0.32^{* * *} \\
(0.11)\end{array}$ & $\begin{array}{c}0.02 \\
(0.11)\end{array}$ & $\begin{array}{l}-0.06 \\
(0.11)\end{array}$ \\
\hline$\Delta$ Unemployment $_{\mathrm{t}}$ & $\begin{array}{l}-0.13 \\
(0.24)\end{array}$ & $\begin{array}{c}0.16 \\
(0.30)\end{array}$ & $\begin{array}{l}0.42^{* *} \\
(0.20)\end{array}$ \\
\hline Unemployment $t_{t-1}$ & $\begin{array}{l}1.99 * * * \\
(0.30)\end{array}$ & $\begin{array}{l}1.21^{* * *} \\
(0.39)\end{array}$ & $\begin{array}{l}1.02^{* * *} \\
(0.33)\end{array}$ \\
\hline$\Delta$ Public education spending ${ }_{t}$ & $\begin{array}{l}-4.20 \\
(3.33)\end{array}$ & $\begin{array}{l}-8.53^{* * *} \\
(2.51)\end{array}$ & $\begin{array}{l}-1.60 \\
(1.68)\end{array}$ \\
\hline Public education spending $\mathrm{t}-1$ & $\begin{array}{l}-9.53^{* * *} \\
(3.12)\end{array}$ & $\begin{array}{l}-8.07^{* * *} \\
(2.53)\end{array}$ & $\begin{array}{l}-7.14^{* * *} \\
(1.99)\end{array}$ \\
\hline$\Delta$ Private education spending $\mathrm{t}$ & $\begin{array}{l}7.92^{* *} \\
(3.25)\end{array}$ & & \\
\hline Private education spending $\mathrm{t}-1$ & $\begin{array}{c}6.54 * \\
(3.96)\end{array}$ & & \\
\hline$\Delta$ Average tax rate $t$ & $\begin{array}{c}0.45 \\
(0.55)\end{array}$ & $\begin{array}{l}-0.25 \\
(0.56)\end{array}$ & $\begin{array}{l}-0.85^{*} \\
(0.47)\end{array}$ \\
\hline Average tax rate $\mathrm{t}-1$ & $\begin{array}{l}-2.20 * * * \\
(0.80)\end{array}$ & $\begin{array}{l}-2.22 * * * \\
(0.50)\end{array}$ & $\begin{array}{l}-2.12^{* * * *} \\
(0.36)\end{array}$ \\
\hline$\Delta$ Non-elderly social spending $t$ & $\begin{array}{c}0.72 \\
(1.12)\end{array}$ & $\begin{array}{c}2.36^{*} \\
(1.36)\end{array}$ & \\
\hline Non-elderly social spending $t-1$ & $\begin{array}{l}-2.68^{* * *} \\
(0.94)\end{array}$ & $\begin{array}{l}-1.98^{* * *} \\
(0.74)\end{array}$ & \\
\hline$\Delta$ EPL regular contracts ${ }_{t}$ & $\begin{array}{l}-8.74 \\
(9.17)\end{array}$ & $\begin{array}{l}-13.65 \\
(11.48)\end{array}$ & \\
\hline EPL regular contracts $\mathrm{t}-1$ & $\begin{array}{l}-12.91 \\
(11.13)\end{array}$ & $\begin{array}{l}-19.49^{*} \\
(9.96)\end{array}$ & \\
\hline$\Delta$ EPL temporary contracts $\mathrm{t}$ & $\begin{array}{l}-7.56 * * * \\
(2.56)\end{array}$ & $\begin{array}{l}-5.75^{* * *} \\
(1.90)\end{array}$ & \\
\hline EPL temporary contracts $\mathrm{t}-1$ & $\begin{array}{l}-5.75^{* *} \\
(2.31)\end{array}$ & $\begin{array}{l}-2.60^{*} \\
(1.35)\end{array}$ & \\
\hline$\Delta$ Bargaining coverage rate ${ }_{t}$ & $\begin{array}{c}0.23 \\
(0.15)\end{array}$ & $\begin{array}{l}0.48^{* * *} \\
(0.14)\end{array}$ & \\
\hline Bargaining coverage rate $t-1$ & $\begin{array}{l}-0.56^{* * *} \\
(0.18)\end{array}$ & $\begin{array}{c}0.16 \\
(0.20)\end{array}$ & \\
\hline$\overline{R^{2}}$ & 0.94 & 0.87 & 0.82 \\
\hline$R^{2}$ without $\mathrm{AR}(1)$ processes & 0.89 & 0.82 & 0.73 \\
\hline$N$ of observations [countries] & $74[20]$ & $84[20]$ & 86 [20] \\
\hline LIS wave dummies & yes & yes & yes \\
\hline Country dummies & yes & yes & yes \\
\hline
\end{tabular}

Notes: * $p<0.1 ; * * p<0.05$; *** $p<0.01$. LIS wave dummies included (not shown). Standard errors corrected for panel heteroskedasticity in parentheses. Panel-specific AR(1) error processes estimated with Prais-Winsten transformation. 